Spring 6-12-2020

\title{
Revisiting CAUTI Prevention: A Multifaceted Approach using Lean Six Sigma
}

\author{
Lisa Ann Behrend \\ I.behrend@usa.edu
}

DOI: https://doi.org/10.46409/sr.OGPH7615

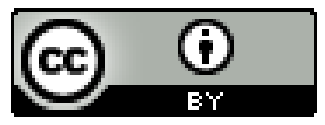

This work is licensed under a Creative Commons Attribution 4.0 License.

Follow this and additional works at: https://soar.usa.edu/scholprojects

Part of the Other Nursing Commons

\section{Recommended Citation}

Behrend, L. (2020). Revisiting CAUTI Prevention: A Multifaceted Approach using Lean Six Sigma. [Doctoral project, University of St Augustine for Health Sciences]. SOAR @ USA: Student Scholarly Projects Collection. https://doi.org/10.46409/sr.OGPH7615

This Scholarly Project is brought to you for free and open access by the Student Research at SOAR @ USA. It has been accepted for inclusion in Student Scholarly Projects by an authorized administrator of SOAR @ USA. For more information, please contact soar@usa.edu, erobinson@usa.edu. 
Revisiting CAUTI Prevention: A Multifaceted Approach using Lean

\author{
Six Sigma \\ Lisa Ann Behrend \\ University of St. Augustine for Health Sciences \\ School of Nursing \\ NUR7803: DNP Practicum III
}

June 2020 


\begin{abstract}
This project identified gaps in policy and processes to improve patient outcomes related to workflow in the catheter-associated urinary tract infection policy and process at a 400-bed hospital in southern California. Even with an evidence-based infection prevention bundle in place, the current process was not working, as demonstrated by high catheter-associated infection rates for the last two years. This project answers the question: Does the use of a comprehensive evaluation of the current policy and process using the Lean Six Sigma quality improvement model influence a reduction in infection rates in patients who have an internal urinary catheter over 15 weeks? Despite published consensus guidelines for the diagnosis, prevention, and treatment of catheter-associated urinary tract infections; a single, evidence-based approach to the reduction of urinary tract infection does not exist. Avoiding the placement of catheters and encouraging early removal are the most effective interventions to prevent infection. The outcomes of the project resulted in a decrease in infections and significant cost reduction for the organization related to patient days and fines. Implementation of teams, nurse-driven protocols, and the establishment of bi-annual staff education were successful interventions. Lean Six Sigma played a significant role in the recognition of practical strategies required to ensure the effective use of proven infection prevention and to decrease the burden of disease correlated with indwelling urinary catheterization.
\end{abstract}

Keywords: catheter-associated urinary tract infection, quality improvement, Lean Six

\title{
Sigma
}


Revisiting CAUTI Prevention: A Multifaceted Approach Using Lean Six Sigma

Elimination of catheter-associated urinary tract infection (CAUTI) is a national patient safety initiative (Rhee, Phelps, Meyer, \& Reed, 2016). Societal and financial influences are driving the need for continuous quality improvement in the health care setting (Gershengorn, Kocher, \& Factor, 2014a). Despite over ten years of evidence-based research, CAUTI remains a danger to patients, accounting for almost $40 \%$ of hospital-acquired infections (HAI) as well as a financial burden for hospitals (Gould, Gaze, Drey, \& Cooper, 2017; Jain, Dogra, Mishra, Thakur, \& Loomba, 2015).

This Doctor of Nursing Practice (DNP) project meticulously assessed the organization's current workflow for CAUTI. Even with the evidence-based CAUTI prevention bundle in place, the current process was not effective, as demonstrated by a standardized infection ratio (SIR) of 1.91 in early 2019. The intervention was designed to garner 'buy in' from frontline staff and physicians. This was accomplished by the formation of a CAUTI Team of frontline stakeholders. Common strategies to improve quality outcomes and guide a successful process change, such as Lean Six Sigma methodologies, were implemented during this practice change project (Makic \& Wald, 2017).

\section{Significance of the Practice Problem}

Hospital-acquired infections (HAIs) continue to be a public health burden despite accelerated efforts to reduce their occurrence. One of the most common HAIs is CAUTIs, which accounts for nearly $70 \%$ to $80 \%$ of infections attributed to an IUC (Sreeramoju, 2019). Approximately $12 \%$ to $16 \%$ of adult hospitalized patients will have a IUC during their inpatient hospitalization (Sreeramoju, 2019). Even though CAUTIs are associated with relatively low mortality and morbidity compared to other HAIs, they still present an extraordinary health problem and financial strain to the patient and the organization (Kuwaiti \& Subbarayalu, 2017; 
Sampathkumar et al., 2016).

Guidelines by The Joint Commission, regarding CAUTI prevention, first appeared in 1981 and then were updated in 2009 and 2014 (Al-Kuwaiti, Homa, \& Maruthamuthu, 2016). These furnished instructions for who should be catheterized, catheter insertion, and care of the catheter (Sampathkumar et al., 2016). Moreover, another way to prevent CAUTI is the nurse's knowledge and attitude toward the prevention of them that can affect outcomes (Jain et al., 2015). When patients are diagnosed with a CAUTI, they succumb to adverse reactions such as discomfort, malaise, fever, and the unnecessary use of antibiotics while in the hospital. They also have an increased chance of having a catheter blockage, urinary tract stones, and malignancy of the urinary tract after a catheter infection (Jain et al., 2015).

Additional complications can arise from CAUTIs, such as cystitis, pyelonephritis, bacteremia, and sepsis. These increase the risk of death (Mohammed \& Hamza, 2019). To avoid these unexpected outcomes, nurses and physicians in collaboration with administration and policy-makers, must work together to enhance the safety of patients and to promote optimal outcomes (Jain et al., 2015; Sampathkumar et al., 2016).

In the United States (US), urinary tract infections account for the highest percentage in HAIs with an estimated annual rate of 560,000 per year, of which 387,550 are related to CAUTIs and are preventable (Mohammed \& Hamza, 2019). Each day, an IUC stays in place, a 3\% to 7\% risk is associated with developing a CAUTI. This percentage equates to approximately 13,000 mortalities over a twelve-month period (Shaver et al., 2018). Escherichia coli is the most common pathogen to cause a CAUTI, and patients will inevitably develop asymptomatic bacteriuria within 24 to 48 hours after catheterization. This bacteriuria can be resolved immediately once the IUC is removed (Gould et al., 2017). 
Because CAUTI is a preventable event, infections and IUC usage rates are reportable findings to the Centers for Disease Control and Prevention (CDC). The CDC's National Healthcare Safety Network (NHSN) is the nation's most widely used healthcare-associated infection tracking system (Quality Measures, 2018). In addition, Leapfrog Hospital Grades is a public reporting group that helps patients choose where to go for hospital care depending upon the grades they receive (Leapfrog Hospital Ratings, 2018).

Since October 2008, the Centers for Medicare and Medicaid Services (CMS) has not reimbursed hospitals for CAUTIs, which can have a significant impact on an organization's budget (Hollenbeak \& Schilling, 2018). Hospitals that do not reduce HAI would face at least a $1 \%$ reduction in Medicare reimbursements. For example, in one year, an organization lost more than \$2.3 million in reimbursements due to CAUTIs. (Scanlon, Wells, Woolforde, Khameraj, \& Baumgarten, 2017).

\section{Framework of the Problem}

Although many pathways to change are available, implementing change in clinical environments can be challenging. Understanding and utilizing the correct change theory in complex clinical practice environments can make the implementation process go more smoothly (Mitchell, 2013). The principal theoretical framework that was used for this DNP project was Kotter's change management theory, which involved eight steps for change: (1) increase urgency; (2) build the guiding team; (3) get the vision right; (4) communicate for buy-in; (5) empower actions and remove barriers; (6) plan for and create short-term wins; (7) don't let up; and (8) make change work (Kotter, 2019). This theory resonated and aligned with this organization's current Lean Six Sigma culture, which promotes the creation of standard work, starting with respect for people and engagement of those who do the work (Cherrafi et al., 2017). 
This DNP practice change project applied each of the eight steps in Kotter's (2019) change management theory. One key element to exemplify Kotter's first step, was to hold a Kaizen event: a rapid, focused application of Lean methods to reduce waste in process areas (Cherrafi et al., 2017). Patient stories were shared among the staff during the Kaizen event to create a sense of urgency for the practice change. To build the guiding team, stakeholders who took part in daily patient care formed a partnership to explain CAUTI prevention procedures. To "get the vision right," setting CAUTI prevention as both the hospital and unit goal created a common vision among staff and promoted success (Kotter, 2019).

The CAUTI Team communicated with and inspired other team members by sharing the successful outcomes on their units throughout the project. Following nurse-driven protocols empowered staff to assess the need for an IUC or for the early removal of one. The Team helped the unit celebrate small wins throughout the process by providing acknowledgement, such as certificates of achievement and recognition during morning huddles, to improve utilization practices. Kotter (2019) mentioned in his seventh step that as one unit started to show success, the process may expand to other units by default, and then the process would start over again. Currently, several units are following new practice guidelines, which by now are well established in unit routines and standards of care.

Kotter's (2019) change management theory approached transformation from an organizational perspective, but to analyze whether the change to the standard of work was effective, the organization employed the Lean Six Sigma model (Cherrafi et al., 2017). The need to have a more predicable CAUTI prevention process prompted this action plan (Al-Kuwaiti et al., 2016; Padula, Duffy, Yilmaz, \& Mishra, 2014). 
Empowering nurses to shape the patient experience and to focus on the delivery of evidence-based practice contributed to improvements in the safety and quality of care (Scanlon et al., 2017). For this organization's culture, Kotter's (2019) management change theory paired with Lean Six Sigma (Kuwaiti \& Subbarayalu, 2017) created an integrative process to achieve evidence-based intervention.

\section{Scholarly Question}

Does the use of a comprehensive evaluation of the current policy and process using the Lean Six Sigma quality improvement model influence a reduction in infection rates in patients who have an IUC over 15 weeks?

\section{Population}

The population comprised adults who were admitted to the hospital. Those who had an IUC placed were included in data collection. Patients most at risk for a CAUTI are female, those with a neurologic or diabetic diagnosis, those with catheters with long indwelling time (defined as being over three days), and those who have been previously catheterized (Jackson et al., 2018; Letica-Kriegel et al., 2019).

\section{Intervention}

First, a multidisciplinary CAUTI Team was created with members from various patient care units, physicians and administrative staff. This group helped with data collection and defining, measuring, and analyzing the current processes to prevent CAUTIs. The team then participated in a two-day Kaizen event (Kuwaiti \& Subbarayalu, 2017), specifically called a Kaizen blitz, to improve the current process of CAUTI prevention. This blitz event is designed to improve a process of an organization. The desired outcomes were improving the frequency of teaching sessions for staff to twice a year, developing improvements to current charting 
requirements, budding future state process maps, and solidifying the sustainability of the project (Fakih et al., 2014; Taha et al., 2017). During the Kaizen event, we discussed categories of waste, current state problems, future state problems, and sustainability elements of the project. Performance gaps were deliberated relating to the knowledge, skills, and motivation of the nursing staff. Finally, organizational weaknesses were examined, such as systems, processes, and organizational culture and communication silos.

Evidence-based protocols demonstrated statistically significant benefits when proper indications, protocols and methods for insertion of IUCs were followed (Lo et al., 2014). The improper use of an IUC, maintenance, and nurse-driven protocols were commonplace in the Intensive Care Unit (ICU), either due to nursing preference, patient or to family request (Mizerek \& Wolf, 2015). Therefore, this project was created to address the issue of high catheterassociated urinary infection rates. A team consisting of nurses, physicians, and administrators came together and utilized the Lean Six Sigma process improvement methodologies. The foremost specific methodology known as define, measure, analyze, improve, control (DMAIC), as well as other quality improvement (QI) tools were utilized. These QI tools were used to assess the current state of CAUTI prevention fully and to review and revise the current IUC insertion, care, and removal policy and processes. Once current policies were revised, education was established for the nursing and ancillary staff. The established CAUTI Team monitored the process to ensure compliance (Rhee et al., 2016). A total of 177 Foley Champions were selected and then educated to follow evidence-based practice specific to proper insertion of an IUC, so that at least two were working on every shift in each unit. Implementing this process, combined with a change management model, improved practices and highlighted opportunities for improvement to sustain the change for the future (Benedicto, 2017). 
During the DNP project, an algorithm (see Figure 1) was created to guide nurses in the prevention of CAUTI. This was founded upon an evidence-based bladder scanner protocol (AHRQ, 2019). This project was the first in the hospital to offer nurses a visual aid to assist in the clinical decision-making process for IUC placement, maintenance and removal. The algorithm was added to the revised policies pertaining to IUCs. In addition, we utilized change of shift huddle time to discuss and evaluate the nurses' knowledge of the protocol and algorithm in real-time.

\section{Comparison}

Prevention bundles have been established to provide a concise and consistent resource for healthcare providers (Ferguson, 2018; Galiczewski, 2016). The CAUTI prevention bundle is perhaps one of the most critical bundles for clinicians because of the complexity of its components and the associated risk factors. This DNP project streamlined the current bundle and offered evidence-based research practice suggestions that increased optimal patient outcomes and reduced the financial burden for the hospital (Durant, 2017).

Several studies have indicated the reduction of CAUTIs after the implementation of the Lean Six Sigma/DMAIC approach (Cherrafi et al., 2017; D'Andreamatteo, Ianni, Lega, \& Sargiacomo, 2015; Kuwaiti \& Subbarayalu, 2017). There is a difference between a standard and a standard of work. A standard is a rule to follow with clear expectations (Kubiak \& Benbow, 2017). A standard of work involves a set of work procedures that will determine the best process methods (Kubiak \& Benbow, 2017). Using the Lean Six Sigma model has helped to establish a standard of work to improve the current CAUTI prevention process (Boettcher, Hunter, \& McGonagle, 2019; Kuwaiti \& Subbarayalu, 2017). 


\section{Outcome}

Reducing the incidence of CAUTI is the ultimate desired outcome. Bacteria develop at a rate of $3 \%$ to $7 \%$ per catheterization day, and CAUTI rates rise in patients with IUCs when they are in place for more than 48 hours (Gould et al., 2017). Following protocols and ensuring nurse compliance in early removal of urinary catheters has been associated with a $17 \%$ CAUTI decrease in the surgical ICU, $29 \%$ in the medical ICU, and $45 \%$ in the coronary ICU (Galiczewski, 2016). Research demonstrates that by adhering to evidence-based protocols, healthcare-associated infections can be reduced by at least $30 \%$ (Galiczewski, 2016). In this organization, CAUTIs were decreased by $60 \%$ from January through December of 2019, following these interventions.

Studies have shown that a performance improvement model such as the Lean Six Sigma/DMAIC process has contributed to the reduction of CAUTI (Kuwaiti \& Subbarayalu, 2017; Rhee et al., 2016). Al-Kuwaiti et al. (2016) used a Lean Six Sigma/DMAIC process to reduce CAUTI rates from 5.6 to 1.2 per 1,000 patient days. For this organization, by implementing Lean Six Sigma methodologies, CAUTI rates went from 1.3 to 0.6 per 1,000 patient catheter days. This reduction in rates equated to a $60 \%$ reduction in CAUTI, which saved the organization a substantial amount.

\section{Timing}

This QI project was sustained for approximately 15 weeks from start to finish. Within this timeframe, multiple strategies were implemented to guide the development of founded opportunities to reduce CAUTIs in hospitalized patients who require ICUs (Makic \& Wald, 2017). In the first week of the session, key stakeholders were identified, and the project charter was completed. The staff gap analysis survey surrounding the prevention of CAUTI went live 
the first week after IRB approval and was available to staff for eighteen days. Once policy revisions were completed, education pertaining to gap results and new evidence-based practice was implemented.

\section{Literature Search Strategy}

Electronic searches of digital databases and application of inclusion and exclusion criteria resulted in retaining 21 articles relevant to the research question (see Appendices A \& B). Literature found was indexed from the following scientific databases: (1) CINAHL Complete, (2) PubMed, and (3) ProQuest. The keywords for all searches were: (a) prevention, (b) catheterassociated urinary tract infections, (c) lean, (d) six sigma, (e) bundle, and (f) process. For all the searches, wide-ranging limiters included time frame, (2014-present), report-type (academic journal, full-text, peer-reviewed), and publication language (English). After these additional limiters were used to narrow the results, the search produced CINAHL Complete 43 citations; PubMed, 44 citations; ProQuest, 55 citations. This search resulted in 142 articles between all three databases; to narrow down the search, additional limiters were applied using the terms quality improvement, and urinary tract infection. Articles were read in full, and exclusion criteria were pediatrics, nursing homes, and type of catheters, cleaning agents, pathogen, surgical patients, ostomy, abstracts, and poster presentations. The following main themes accumulated from the extensive research related to the research question.

\section{Literature Search Results and Evaluation}

The online search resulted in 142 articles between all three databases. The three databases utilized produced the following results: CINAHL Complete 43 citations, PubMed, 44 citations; and ProQuest, 55 citations. Eliminating the duplicates, keeping the research within the last five years, and using limiters to narrow down the search reduced the total number of articles. A PRISMA flow 
diagram expresses the flow of literature results and evaluations, with all the inclusion and exclusion criteria (see Figure 2).

Each of the remaining articles was reviewed for its evidence level and quality to yield a combination of good to high-quality articles pertaining to the PICOT question (see Appendix A). Evidence levels and quality varied among the articles, and details can be found in Appendix B.

\section{Themes from the Literature}

In reviewing the abundant research, several themes emerged in the literature.

Considerable research was shared with a wealth of value toward preventing and lowering the incidence of CAUTIs. The following are the topmost three topics that were discussed throughout the literature.

\section{CAUTI Team}

One of the foremost themes that resonated throughout the literature was the creation of the CAUTI team. Most of the research mentioned that a CAUTI team was implemented at the beginning of the implementation process. Having a CAUTI team was a natural first step of many toward decreasing CAUTIs (Scanlon et al., 2017). The implementation of CAUTI Teams, in conjunction with the bundle components, dropped overall rates of CAUTI from $2.4 \%$ (20 out of 828 cases) to a rate of $0.7 \%$ (Fakih et al., 2016; Regagnin et al., 2016; Rozario, 2018). The inclusion of a physician champion was a worthwhile addition to the team, and one of our Intensive Care Physicians is currently on the team. The CAUTI teams play a significant role in daily accountability by rounding each morning and verifying with the primary nurse and physician the indwelling catheter is warranted (Scanlon et al., 2017). The CAUTI team currently rounds both weekly every Thursday, and daily during multidisciplinary rounds in the ICU. 


\section{Pre-Insertion Algorithm}

Research demonstrated that nurses and physicians' attitudes regarding the placement of an IUC varied considerably (Jain et al., 2015). Having these contradictory beliefs triggered unpredictability in decision-making on when an IUC was suitable for each clinical situation. Several patient and non-patient influences, including clinical location, resources, patient age and gender, and staff workload, also impacted each decision (Jain et al., 2015). Assessing when the benefit of an IUC outweighed the risk could be problematic due to conflicting goals (Murphy, Prieto, \& Fader, 2015).

Once an indwelling catheter is removed, research data suggested initiating an algorithm for intermittent straight catheterization could be beneficial (John et al., 2015; Lo et al., 2014; Sampathkumar et al., 2016; Smith, 2015). Developing an algorithm to manage urinary retention postoperatively or after removal of a IUC by day three would help to reduce Foley reinsertion when not warranted (Scanlon et al., 2017). An algorithm not only provides clarity, but also decreases the workload of the nurses to aid in the prevention of reinserting an IUC (Murphy et al., 2015). Therefore, a pre-insertion algorithm was established per evidence-based research and initiated into practice and policy.

\section{Education}

Finally, it was reported that early engagement in prevention protocols and targeted education led to increased knowledge, changes in behavior, and renewed CAUTI awareness among nursing and medical staff (Gould, Umscheid, Agarwal, Kuntz, \& Pegues, 2019; Menegueti et al., 2019). The frequency of nursing staff education during the year had a significant impact on nurses' knowledge gaps and was instrumental in sustained compliance with bundle use. The recommendation for reducing knowledge gaps and increasing compliance was 
twice per annum (Gesmundo, 2016; Parker et al., 2017; Shaver et al., 2018). Before placing an IUC, physicians and Foley registered nurse champions (RNC) must thoroughly evaluate the indications and consider whether an alternative device would be more appropriate. The goal is not to place a catheter but to use alternative methods.

\section{Practice Recommendation}

Urinary catheter use is a common yet potentially dangerous intervention (Peate \& Gil, 2015). Although this practice has been utilized for years, the reductions of UTIs are small in comparison to outcomes when CAUTI bundle protocols have been set in place (Galiczewski \& Shurpin, 2017). For the patients who acquire a CAUTI, it is much more than an unnecessarily increased length of stay. They bear the physical cost of pain and treatments to prevent the risk of sepsis. Associated time out from work can lead to financial burdens for their families (Carter, Beitmeier, \& Goodloe, 2014). The research for CAUTI prevention and reduction has proven successful (Durant, 2017; Kachare, Sanders, Myatt, Fitzgerald, \& Zervos, 2014; Saint et al., 2015). Changing the culture of an organization and improving collaboration is paramount to the success of CAUTI decline (Scanlon et al., 2017)

Knowing all of this, CAUTIs have not decreased in the US since that last update on prevention (Rhee et al., 2016). What is left to do? Numerous studies have shown that adding the Lean Six Sigma methodologies have decreased CAUTIs substantially (Boettcher, Hunter, \& McGonagle, 2019; D'Andreamatteo et al., 2015; Kuwaiti \& Subbarayalu, 2017; Rhee et al., 2016). Improving the current process of the CAUTI bundle delivery does require a system redesign, and so implementing the Lean Six Sigma methodologies (Padula et al., 2014) benefitted this organization. 
Recommendations for practice change consisted of creating a CAUTI team to facilitate changes in practice to reduce CAUTIs. Research findings indicated the development of such a team contributed to quality improvement, empowered staff, and provided safe, quality care to the patients (Scanlon et al., 2017). In addition to these benefits, creating a CAUTI team did ultimately change the culture of the organization. Most importantly, it held staff accountable for the sustainability of the project, which was the real challenge (Boettcher et al., 2019; Gershengorn, Kocher, \& Factor, 2014b). Evidence indicated twice yearly staff education was beneficial to provide best practice and sustainability throughout the year (Scanlon et al., 2017). These education sessions, along with daily rounding by the CAUTI team, helped to reduce CAUTI (Scanlon et al., 2017).

Application of the Lean Six Sigma methodologies explicitly using the DMAIC method (Kuwaiti \& Subbarayalu, 2017) evaluated where process changes could occur to streamline current practices in reducing CAUTIs. This process introduced an algorithm that included recommendations for: a) addressing straight catheterization by nursing staff; b) best practice guidelines for maintenance; and c) best practice for removal of IUCs (Kuwaiti \& Subbarayalu, 2017; Rhee et al., 2016).

Additionally, facilitating evidence-based huddle inquiries (Bernstein et al., 2016; Felix, 2014) pertaining to CAUTI was a quick reminder to keep staff engaged daily in the quest for Foley free days, and increased patient safety and greater satisfaction (Carter et al., 2014).

\section{Project Setting}

This DNP project was conducted at a 400-bed hospital in southern California, which was a primary acute care hospital setting. Typical adult patients who were admitted to this hospital 
ranged from age 18 and over and were a heterogeneous cultural mix. This population included a large proportion of Vietnamese, Mexican, Armenian, and Hawaiian clients.

\section{Organizational Culture}

Organizational culture was considered to be the prerequisite for teamwork and played a huge role in job satisfaction (Körner, Wirtz, Bengel, \& Göritz, 2015). Various meetings, including, but not limited to, the following, facilitated interprofessional collaboration: nursing grand rounds, nursing forum, and quality improvement meetings. Opportunities for improvement were identified by electronic safety and risk management (ESRM) submissions, representatives from different units attended these sessions and collaborated to problem-solve. Any organizational change was facilitated by following Lean Six Sigma guidelines to improve workflow and irradiate waste (Nordin \& Deros, 2017). Administration rounded weekly on the units to support staff and address concerns, while directors were visible with an open-door policy. Managers addressed daily workflow to throughput and supported staff by rounding on the units throughout the day. Each unit had a unit practice council that had three components to its structure: education, team building, and evidence-based practice. Daily huddles were conducted between each shift to communicate unit changes or nurses' concerns. This helped to bring staff together and work toward optimal outcomes for the team and patients.

\section{Organizational Structure}

The hospital was represented by a three-tier organizational structure (Christophersen, 2018). At the top was the chief executive officer (CEO), who collaborated with the governing board and the chief of staff. The team on the second level who reported to the CEO was the chief operating officer (COO), chief nursing officer (CNO), chief financial officer (CFO), and the chief human resources officer (CHRO). Each team member was responsible for several 
departments associated with his or her job title. The associate CNO (ACNO) had several various departments that were her responsibility to run and manage. Collaboration was sustained each week with department directors during the Executive Nurse Committee meeting.

\section{Organizational Need}

According to the Health Services Advisory Group (HSAG), the project site had a standardized infection ratio (SIR) of 1.91 for CAUTI in 2016, which was significantly higher than the national standards of care of less than 1.0 (NHSN, 2019). In 2017, there was an average SIR of 1.93, and in 2018, the SIR was 1.81 (National Healthcare Safety Network SIR for CAUTI Data for Hospital Inpatient Quality Reporting, 2017) . These figures indicated a slight decrease, but there was still a need for improvement.

Due to the previous year's SIR statistics, a gap analysis was completed on catheter insertion and maintenance of the catheter. The results suggested there were too many variables to achieve the successful insertion a Foley catheter and maintenance of the system (Zorich, 2018). Initially, a collaborative analysis was done to get a baseline of strengths, weaknesses, opportunities, and threats (SWOT) before starting this DNP practice change project (see Figure 3). A brief overview of strengths included support from organization, materials already in place, and education support. Weaknesses were determined to be increased lengths of stay for patients, an increased financial burden to the organization, and a lack of staff buy-in to follow the CAUTI bundle. Opportunities were the ability to halt the recent increase in CAUTI rates and initiate a decline, to share practices, and to gain support from vendors by increased collaboration to provide the most updated strategies in evidence-based care. Lastly, some threats considered were patients choosing to go elsewhere for treatment, low CMS ratings, and putting the reputation of the organization at risk. 


\section{Organizational Support}

Initially, support was confirmed by the CNO, but there were others involved as well. This project had support from administration, primary, secondary, and key stakeholders. The decision, authority, need, connection, and energy (DANCE) method (Kogon, Blakemore, \& Wood, 2015) was used to determine the strengths of each stakeholder so that they would be able to provide support throughout the project to the best of their ability. Choosing stakeholders who could make decisions, had the authority to grant permission, who needed the benefit of the project, who had connections with resources, and who had positive energy to affect the project success was achieved using the DANCE method (Kogon et al., 2015).

The key stakeholders in the group needed to have a decision maker who had the authority to grant permission to proceed with the project and who would candidly benefit from the desired outcome of this practice change (Kogon et al., 2015). These primary stakeholders were the CEO, CFO, and CNO. Secondary stakeholders needed to connect with other leaders and resources that could help to remove roadblocks or exert influence to ensure project success. Various unit directors eagerly filled this role to help advance this project. To facilitate the everyday workings of the practice change strategy, the key stakeholders were nurses, physicians, and managers who made up the first CAUTI Team.

\section{Sustainability Plan}

By identifying the organization's knowledge base, and having this data readily accessible to those who need to use it, an organization can distribute information efficiently to maintain organizational memory (Kubiak \& Benbow, 2017). Per Six Sigma, four major components ensure the sustainability of any project: reviewing gaps of knowledge, documenting findings, educating and monitoring process metrics (Kubiak \& Benbow, 2017). 
Initial training guided by the first gap analysis was essential to direct where education was needed most. Follow-up by a gap analysis is recommended every six months due to the new staff hired and merely as a refresher to the staff. Recurring training is useful to minimize deterioration in process performance over time and staff complacency (Kubiak \& Benbow, 2017). Education will be accomplished by annual clinical validation, short in-services on the units, and learning webinars on the organization's webpage (Kubiak \& Benbow, 2017).

Continued rounding by members of the CAUTI team will provide "just-in-time" Lean Six Sigma-based education (Kubiak \& Benbow, 2017). In addition, the CAUTI team will continue to print out documents each shift to determine which patients have an IUC and how long it has been in place. The printed material will help to prioritize daily rounds. Additionally, during change of shift huddle, nurses will be reminded to remove unnecessary urinary catheters and kept up-todate on the current CAUTI data.

A monthly balance scorecard evaluation will help with the strategic planning and management of this project. It also provides a visual tool to explain to the staff what the goals are for the organization. Balanced scorecards are used to quantify and arrange for feedback to the hospital (Shrivastava \& Shrivastava, 2019). Additionally, key performance indicators, such as outcome and process measures, will be evaluated to help measure progress against key goals of the hospital (Tyagi \& Singh, 2019).

Lastly, to sustain this project, monitoring must be conducted to ensure the gains are maintained and to determine when additional improvements are required. There are several tools that Six Sigma uses to accomplish this (Kubiak \& Benbow, 2017). Control charts and grafts will be used monthly to monitor the performance of the process. Looking at process capability studies will ensure the project provides satisfaction to the customer and determine where openings for 
improvement can occur. Continuous monitoring of key performance indicators each month, ensuring a balanced scorecard, and monitoring the financial impact of the improved process to the organization highlight areas for improvement (Kubiak \& Benbow, 2017).

\section{Project Overview}

All organizations have goals, either long-term or short-term, to help the company conduct its business in a strategic way that is easily understood. A mission statement describes what the organization does and why. The vision statement is a set of long-term goals and aspirations and focuses on the organization's future. Clearly stated objectives are the means for accomplishing an organization's mission (Smith, 2015). The following sections outline the project's mission, vision, and objectives.

\section{Mission Statement}

The mission of this DNP project was to use evidence-based research to increase nurses' knowledge of the importance and use of CAUTI bundles and nurse-driven protocols to prevent harm to patients and to reduce the rejected claims cost when there is an associated HAI. The mission of this organization provides a framework to have patients live happy and healthy lives. This aligns with the project mission because preventing CAUTIs will lead to happier and healthier lives.

\section{Vision}

The vision of this DNP project was to empower the nurses to use evidence-based interventions to promote optimal outcomes for adult patients who require an IUC.

\section{Objective}

At the conclusion of this 15 -week practice change DNP project, the medical and nursing hospital staff will have improved their knowledge about the requirements for intermittent catheterization versus indwelling catheter related to best practice. 


\section{Short-term Goals}

A short-term goal was to have the CAUTI bundle assessment done within four weeks using a LEAN Six Sigma process and DMAIC analysis (de Freitas, Costa, \& Ferraz, 2017). The existing CAUTI prevention bundle was amended within a four-week timeframe by conducting a Lean Six Sigma /DMAIC analysis. This analysis was accomplished through eight hourly meetings over the four weeks.

Another short-term goal was education being completed within four weeks. Along with the training, the goal was a $75 \%$ improvement in the knowledge gap of nurses from the presurvey compared to the post-survey results. This goal was achieved and surpassed by $15 \%$. A 90\% improvement was indicated in the CAUTI prevention knowledge gap of nurses from the pre-survey compared to the post-survey. This was accomplished by class lectures and in-service education in real-time. The nurse-driven protocol was used to manage $95 \%$ of patients with IUCs.

\section{Long-term Goals}

There were several long-term goals for this project, including the reduction of CAUTI by $90 \%$. This goal was not met because the actual decrease was $60 \%$. Another long-term goal was a $75 \%$ decrease in the utilization of Foley catheter kits throughout the hospital. This goal was not reached, as $23 \%$ fewer Foley catheter kits were used. The last long-term goal was the organization's key performance indicators associated with CAUTI were to be below national standard guidelines. This goal was accomplished by decreasing device days compared to the national standard of and SIR associated with CAUTI (see Figure 4). 


\section{Risks}

Unintended risks for the project that was encountered included putting the patients at risk of a CAUTI even though CAUTIs are preventable. Increasing the patient's length of stay and increased stressors to the patient and family were also possibilities. Primarily these were possible financial burdens for them for the organization, as CMS would have rejected the claim in the case of a confirmed HAI. Moreover, nurse and physician buy-in were essential to this project. For example, if the sense of urgency for the need for change had not been realized, this would have put the project at risk (Kotter, 2019).

\section{Project Description}

The design of this DNP practice change project was to foster a collaborative approach to reevaluate the CAUTI prevention bundle process, improve catheterization practices and reduce CAUTIs in the hospital. The plan to accomplish these goals had several practical components that helped to sustain the project. Two distinct but inter-related frameworks guided intervention and examination of the data: Kotter and Lean Six Sigma.

\section{Kotter Change Model}

The Kotter eight-step change model is designed to improve an organization's ability to change and to increase its chances of success (Kotter, 2019). The first step was to create a sense of urgency, which was an essential step in the process. By making staff aware of the need and importance of the change, support was then created. Creating awareness was accomplished through frank discussions about the organization's current benchmark data and national benchmark statistics, opportunities and crises (Kotter, 2019). This theory resonated and aligned with the organization's current immersion into the Lean Six Sigma culture, which promotes the creation of a standard of work, starting with respect for people and engagement of those who do 
the work (Cherrafi et al., 2017). This theory was embedded in the description of the Lean Six Sigma process/DMAIC (Kuwaiti \& Subbarayalu, 2017).

\section{Lean Six Sigma Overview}

The major framework of this project was created utilizing the Lean Six Sigma/DMAIC methodologies (Kubiak \& Benbow, 2017; Kuwaiti \& Subbarayalu, 2017). This project defined, measured, and analyzed the current CAUTI prevention process being used by the organization. It not only defined the problem, but it extended to qualification of the problem, identification of its root causes, and implementation and verification of the solution. Finally, this project offered a process to maintain gains and to continue reviewing solutions through each step. A CAUTI team was formed that included secondary and primary key stakeholders. The team consisted of six nurses, quality administration, infection control staff, directors, and an intensive care physician. The interprofessional collaboration was essential and was easily accomplished with representative members from all different departments.

\section{Barriers}

Organizational change can be challenging at best. This project did not have many barriers, but they did occur. For instance, education rooms were not always available within the 15-week time frame, and CAUTI prevention bundle steps were not always followed. With proper management from the beginning, these barriers could have been reduced. The CAUTI team used a risk matrix tool and the probability formula when the initial kickoff meeting occurred (Kubiak $\&$ Benbow, 2017). These tools led to a better management plan than initially intended (Kogon et al., 2015).

Another barrier was a lack of educational time for all staff. Some nursing staff were on vacation, out sick, or just did not make the training sessions due to other commitments on their 
days off. Additionally, physicians were not educated in the new process due to time constraints.

The solution for this at the next opportunity would be to make changes to the current electronic medical record. To help facilitate these changes, a learning station would be set up in their private dining room with an opportunity for questions and answers.

Research findings indicate that visual cues aid in reducing CAUTI (Jones, Meyrick, Bath, Dunham, \& McNulty, 2019). During the Kaizen event, it was determined that adding pop-up windows after a physician has signed into their patient's portal was too expensive. The original idea was to have a pop-up window appear if their patient had an indwelling catheter with the hope that would make it easier for the physician to click on the order to remove the IUC. The electronic pop-up reminder for the physicians is still pending and will be introduced into next year's budget.

\section{Project Management and Leadership Role}

Professional collaboration was the foundation of this entire DNP practice change project. Without cooperation from stakeholders and team members, this project would never have come to fruition (Kotter, 2019). This DNP student had to utilize leadership skills that would bring out the best in others. Leadership style was imperative to keep the team focused, increase energy, and prevent loss of momentum throughout the project (Maxwell, 2016). Encouraging the group to share the big picture instead of being used as tools to get a job done was most important. Open communication with stakeholders fostered ownership and helped others to see the big picture of the project together (Maxwell, 2015, 2016).

\section{Schedule}

The IRB process was initiated with the completion and submission of an application to MetroWest for approval. The MetroWest approval letter was received. Subsequently an 
additional application from the University of Saint Augustine (USA) was needed and therefore completed and submitted. Five weeks later the second approval letter from USA was received.

Baseline data was obtained from the organization, and education was started for all nurses who were designated as Foley Champions. In total, 170 nurses were trained following evidence-based research. That same week, gap assessment was made available to all nurses on the organization's homepage to review and complete. The CAUTI Team was established, and the first meeting was held on September 29, 2019. Review of current policies started immediately with changes supported by available evidence, and revised versions were then sent to various committees for approval. The document approval committee gave final approval, and staff education commenced house wide.

\section{Budget}

The direct cost for the organization consisted of meeting hours for nurses and administration, and then education hours for staff. The estimated cost for educating nurses was based on salary, time, and resources needed. For the CAUTI Team, several one-hour meetings occurred during this project. A vast majority of the hours spent on this project were related to the time spent by this DNP student completing this project.

The cost of this project could be considered insignificant compared to the expense of one CAUTI. Length of stay increases by 2 to 4 days due to CAUTI (Control \& Prevention, 2017). The cost of providing care for one patient for one day is estimated to be $\$ 3,200$. Multiplied by the lowest estimation of two extra days of hospitalization, means an added expense of $\$ 6,400$ for every patient who acquires a CAUTI (see Figure 5). This is a cost that is not reimbursed by CMS, a charge the hospital has to absorb. Zorich (2018) estimated the organizational for one CAUTI is an average of $\$ 10,000$ (Zorich, 2018). 
Cost savings were apparent due to a significant decrease in Foley kit utilization and an increase in alternative urine collection methods. The financial burden was further decreased due to the reduction of CAUTI and length of stay. Also, because nurses were taught in 15-minute micro sessions about the new CAUTI prevention policies and procedures during the shift, there was a significant reduction in hourly cost when educating staff by the CAUTI team. The over-all financial savings was $\$ 242,449.00$ (see Figure 5).

\section{Project Evaluation}

Information collection methods were broad enough to ascertain and measure the outcome, as well as congruent with the study plan. It was essential to select information collection methods and participants that suited the DNP project goal to decrease CAUTIs. Evaluation of this project and its effectiveness was accomplished on a continuous process by using specific tools. In contrast, a formal assessment was done by pre- and post-tests and by daily rounding on the nursing units. Team members instituted new quality checks to enhance the success of the project.

\section{Selection of Participants}

One of the first steps was defining and managing the roles that are required for the project (Kogon et al., 2015). A collaborative approach with unit directors was initiated in choosing staff for this project. Finding staff members who were appropriately qualified to join the CAUTI Team was a challenging process. A common mistake is to assign whoever was available to the team (Kogon et al., 2015). The nursing staff that worked part-time or desired to enhance their nursing profession were invited to join the team. Two physician champions personally asked to join the CAUTI Team. 


\section{Progress and Quality Checks}

After each phase of the DNP practice change project, it was imperative to evaluate the progress. There were diverse ways to accomplish this, either by statistical analysis or project management skills (Kogon et al., 2015). An example was to compare SIR values each month as well as balance scorecard indicator goals for the organization. Progress was assessed at various valid points of the project to ensure the schedule for the timeline of this project was on time.

Additionally, quality checks were analyzed, budget concerns were managed, stakeholder satisfaction was verified, and monitoring of overall performance was performed. Moreover, it was crucial that the project manager provided transparent communication throughout this process, especially if the deliverables were off scope; stakeholders needed to be aware of the good as well as the bad of the process (Kogon et al., 2015) Sharing a project status report once a month helped to facilitate this communication to the key stakeholders (Kogon et al., 2015). The primary stakeholders in these phases were patients, nurses, physicians, administration, and quality management.

\section{Formative Evaluation}

To evaluate the effectiveness of the project, sets of tools such as DMAIC steps, benchmark, and balanced scorecard indicators were utilized. Evaluating the key performance indicators and SIR data has determined if the project met or exceeded national patient standards (Al-Kuwaiti et al., 2016; Lo et al., 2014). Kotter's (2019) change management model's eight steps were followed as a guide while evaluating the practice change.

The project started with an evaluation of the nursing staff's knowledge about preventing CAUTI using a pre-test to establish a baseline (Moran, Burson, \& Conrad, 2020). An elevenquestion survey was specifically designed and used to address knowledge gaps in CAUTI 
prevention (Appendix C). For this research project, two questionnaires were utilized to create a survey regarding the indication, use, management, and discontinuation of an acute care indwelling urinary catheter among nursing staff. This survey was administered through an electronic platform. The education plan was developed from the survey results. Five of the eleven questions were adapted from existing scales, including Dumont and Wakeman's (2010) research and six questions from Ferguson (2018) (Dumont \& Wakeman, 2010; Ferguson, 2018). A total of 11 questions were compiled to examine nurse's knowledge and address subsequent gaps. The evaluation of the scale's initial strength (reliability) in terms of appropriate questions was accomplished by comparing the Agency for Healthcare Research and Quality Toolkit (AHRQ, 2019) and the CDC (Gould, Umshcheid, Agarwal, Kuntz, \& Pegues, 2009) date standards of care for target variables.

To evaluate the process elements that made up the CAUTI bundle, the plan included the use of Lean Six Sigma/DMAIC methodology (Kubiak \& Benbow, 2017) along with the project charter, needs assessment using a SWOT analysis, balanced scorecard, Lean Six Sigma methodologies, process flow charts, root cause analysis, and action plans when required (Berman, Raval, \& Goldin, 2018; Kuwaiti \& Subbarayalu, 2017; Moran, Burson, \& Conrad, 2020).

The CAUTI Team was assembled and used various tools to break down the current process into four parts: waste, the current state of the problem, future state, and sustainability. In assessing the current state, performance gaps and organizational gaps were evaluated. Deliverables consisted of policy revision to reflect the latest evidence-based practice, nurse competencies for Foley Champion education, attestations to reflect new equipment being used, 
new order sets, and a post-removal algorithm. Education commenced over a four-week period during various hours to ensure all nurses had a change to attend.

\section{Summative Evaluation}

An initial summative evaluation utilizing histograms and frequency distributions was helpful because the data values and specified ranges of continuous data led the researcher towards gaps. The benchmark for success in this study was having a SIR below the national guidelines of 1.0 (National Healthcare Safety Network SIR for CAUTI Data for Hospital Inpatient Quality Reporting, 2017).

The pre- and post-test used was a reliable tool for assessing the nurse's knowledge of CAUTI. This test was taken once before education was provided and then repeated after the education portion was presented. The survey covered knowledge gaps and process evaluation concepts. The patients' admissions sheets and the electronic medical record (EMR) provided most of the variable data values. Examples included: age, gender, indwelling Foley days, admitted with a Foley catheter, removal day, peri care, Foley Champion (second nurse), and the policy followed.

\section{Data Analysis}

To decide if the evidence-based practice change was beneficial, primary data were collected before and during the project to monitor and track variable trends. Data collected consisted of the number of Foley and straight catheter kits, condom catheters, and PureWick devices used. Additionally, education hours, extended patient hospitalization stay, and CAUTI reduction totals were compared. 


\section{Protection of Human Rights and Privacy}

Patients were kept safe by utilizing the standards of care provided by the organization. These interventions were implemented as daily routine care supported by evidence-based practice. The Health Insurance Portability \& Accountability Act (HIPAA) regulations were enforced by previously set practices. This organization used the patients' medical record number for identification purposes.

\section{Project Evaluation Results}

To determine if the results of the project were significant, several areas were evaluated and discussed. These included participants and environment as well as healthcare quality improvement measures.

\section{Participants and Environment}

The population examined was adults admitted to the hospital. While in the acute care setting, the patients who had an IUC placed were included. Patients most at risk for a CAUTI were females, with neurologic or diabetic diagnosis, with catheters with long indwelling time over three days, and those who had been previously catheterized (Jackson et al., 2018; LeticaKriegel et al., 2019). This DNP project was conducted at a 400-bed hospital in southern California, which is a primary healthcare setting. Typical adult patients who were admitted to the hospital ranged from ages 18 and above and were from various cultures. This included a large heterogeneous population of Vietnamese clients, as well as Mexican, Armenian and Hawaiian clients.

\section{Outcome in PICOT Question}

Reducing the incidence of CAUTI by $60 \%$ in 2019 was the ultimate outcome. This was accomplished by following CAUTI bundle protocols, ensuring nurse compliance in removing 
urinary catheters early and proactively preventing IUCs from being automatically inserted. In total, there were 15 CAUTI in 2018; in 2019, there were only 6.

\section{Degree of Project Success}

This project's success was qualified by the short- and long-term goals. This DNP practice change project did meet some of the various short- and long-term goals. The objectives not achieved will be reevaluated in three months during the sustainability phase. The determination of the success of this project was broken down into several specific measures. These four measures are: outcome, process, balancing, and financial ("Science of Improvement: Establishing Measures," 2020).

Outcome. Meeting the "gold standard" by CDC and being transparent through Leapfrog and Healthgrades is paramount to show consumers the organization is meeting National guidelines. National guidelines for success would be demonstrated with a SIR below 1.0 (National Healthcare Safety Network SIR for CAUTI Data for Hospital Inpatient Quality Reporting, 2017). The 2019 value was 0.644 , which was a substantial decrease from the 2018 figure of 1.63. This represented a significant improvement in patient outcomes and cost recapture for the organization.

Process. The project conducted data collection on order set documentation to evaluate compliance, quality/infection control data, and reduction in CAUTIs. The CAUTI rates dropped from 1.3 to 0.60 per 1000 catheter days in 2019, which saved the organization money (see Figure 4).

Balancing. This project assumed reduction of CAUTI would increase patient satisfaction and decrease length of stay. While there appeared to be a potential association between patient satisfaction and CAUTI reduction, it merits further exploration in future projects. 
Financial. Project benefits were measured by comparing supply usage before and after implementing practice changes (see Figure 6). Additionally, collecting monthly data on CAUTI throughout the hospital helped to determine any differences. Project cost - was lower than anticipated because education of nurses about the new policy changes was conducted via 15minute micro sessions during their shifts. Therefore, the nurses did not accrue over-time, which could have amounted to substantial financial burdens with 975 nurses on staff.

\section{Statistical Analysis}

There were 165 responses in the pre-test $(n=165)$ and 140 responses in the post-test $(n=$ 140). The responses were 25 fewer in the post-test due to attendance. Each of these quizzes was made available for a three-week period so the nurses could participate. Education for the nurses was conducted during classes that were 15 minutes in length. These classes took place between the administrations of the two quizzes. The pre-quiz and post-quiz results were analyzed using IBM PCSS (Field, 2018) statistical software. Given the mean test scores of the pre-test was $68.8 \%$ as compared to $90 \%$ on the post test, and given the standard deviations for each, based on this information, the $t$-test result was -5.173 , which corresponded to a $\mathrm{p}$ value of $2.44 \times 10^{\wedge}-7$. This indicated that the mean was significantly higher for the post-test when compared to the pretest.

Standard deviation for the pre-test answers, which was $(\sigma=31.15)$, showed that the answers provided held statistically significant variation. This variation indicated that the nurses did not have a consistent knowledge base from which they were making clinical decisions. Conversely, the standard deviation for the post-quiz answers, which was $(\sigma=14.21)$, was more precise, demonstrating better understanding and positive clinical knowledge transfer. The standard deviation difference verified increased consistency when compared to the pre-test. 


\section{Discussion and Implications}

During this 15-week practice assessment and change, several relevant results emerged. The preeminent result was the outcome of reduction in CAUTIs. This organization had 15 CAUTIs in 2018 and 6 for 2019, the year of this study. Another data point was the SIR, which was zero in the last quarter of 2019, and was 1.629 in the previous quarter of 2018. This also represented a significant positive change showing a reduction in catheter days because nurses followed policy and removed urinary catheters in a timely manner.

Supply data was compiled comparing 2018 and 2019 usage of Foley and intermittent straight catheter kits, condom catheters, and PureWick devices. A total of 1,147 fewer Foley kits

were used. Predictably, the use of alternative methods was collectively increased by 3,240. These changes in urine collection methods showed nursing staff were following the new protocol, which increased patient safety and financial savings.

The implementation of the practice change was successful. Weekly transparent communication with stakeholders helped to facilitate the planned project. Some aspects of the project were delayed a few days to a week but ultimately they were accomplished within the time frame allowed.

The process measure goal was to decrease the amount of preventable CAUTIs. The goal was accomplished by having nine fewer infections during the year 2019. Implementing evidence-based practice in conjunction with Lean Six Sigma, methods produced promising comparative results. Without the collaboration of the newly implemented multidisciplinary CAUTI Team, the reduction of HAIs related to IUC would potentially have been the same or higher. 
The data collected at the end of 2019 showed that a process change occurred. With the reductions of CAUTIs alone, the organization saved $\$ 90,000.00$ in costs. These findings are essential in that meeting benchmark standards can protect additional reimbursement. The benchmark grid for the year 2019 demonstrated significant improvement in each unit in the prevention of CAUTIs.

The most important factor is providing optimal outcomes for the patients during their admission. Research has demonstrated that each patient who develops a CAUTI must spend an average of four more days in the hospital.

The organization's reduction in CAUTIs reflects in a $60 \%$ drop from the previous year. The decrease points to a possible association comparable to published reports in the literature (Dascomb et al., 2016; Fasugba et al., 2018; Gray, Skinner, \& Kaler, 2016; Lo et al., 2014), but requires further research confirmation. Benchmark data collected for 2019 showed a reduction to 0.91, where less than one is optimal. The organization, however, is setting a goal of 0.41 , which should be obtainable.

The most critical relevance to all these findings is the opportunity to save patients' lives. By educating staff and implementing evidence-based practice, the organization has already shown improvement. With continued organizational support, including creating opportunities to sustain these improvements, the organization will further demonstrate to the local community that it provides safe care.

\section{Limitations}

Limitations of the DNP practice change project were few, but significant. Time to implement the process change to see sustainability was not enough; although, with the time allotted, change had occurred. During the project timeframe, the physicians were not informed of 
the education and considerable modifications made so that the nursing staff and medical staff could be on the same page about changes or additions to the policy that was made. Visual aids were not finished in time, which research demonstrated could make a difference in the reductions of CAUTIs. Moreover, from the kaizen event, the suggestion of a pop-up reminder to remind physicians about IUC remains to be implemented. This was brought to the stakeholder's meetings and would have to be introduced into the next year's budget upon approval. The next step would be to follow-up on some of the limitations of the project. The team recommended that education be continued education bi-annually and that the CAUTI Team support both nursing and medical staff, to stay motivated in the prevention of CAUTIs.

\section{Dissemination}

Once the new protocol was established, a stakeholder meeting was conducted where control charts of process changes were reviewed, as well as staff survey results. It was essential at this point to keep the communication flow open so that transparency was sustained for this project and future ones too. More importantly, at this time, data presentation about scorecard and dashboard results was handed out, and a failure analysis result was shared as well. Budget analysis on product usage was detailed and showed fewer IUC kits were used, and increased alternative methods, such as intermittent catheter kits were used. Each step of the CAUTI prevention bundle was described in full detail so that it can be reproduced. A question and answer session was open after each meeting.

Sharing the results through staff communication was completed via online modalities (screen saver, daily news, and flyers), during mid-shift huddle announcements, in the morning during shift change, and email correspondence. Another way this information was shared was during a Nursing Grand Rounds (NGR) session. NGR is an hour-long lecture on evidence-based 
practice by front line nursing staff that is held each quarter of the year to promote best practices.

Moreover, our $\mathrm{CNO}$ held nursing forum meetings twice a month to update nursing staff on the latest practice changes and benchmark results from the previous month. The project data was shared, and reinforcement of the CAUTI prevention guidelines was discussed to nursing staff present on two dates.

Outside the organization, the dissemination of project results is being planned to through the upcoming American Association of Critical Care Nurses - National Teaching Institute (NTI) conference in May 2021. The timeframe for poster presentation submission is July 14 through September 15, 2020. NTI promotes research and the advancement of critical care nursing through projects like this.

Additionally, this doctoral project will be shared through SOAR, which is an electronic submission database to demonstrate scholarly work supported by the University. By making this project available to the public, it allows the results to be more visible and cited by other academic researchers and fosters collaboration. Tracking of downloads of studies from different parts of the world can be recorded for future reference and possible research. Finally, dissemination of this project through the Virginia Henderson International Nursing Library will further extend the project reach.

\section{Conclusion}

Lean Six Sigma is a quality improvement methodology that was used to improve efficiency and promote optimal clinical outcomes in healthcare. Conducting specific methodologies such as a kaizen event to determine areas of waste and performance gaps promoted safe practices throughout the process and satisfaction for both staff and patients. The delivery of exceptional healthcare using this method requires an interprofessional team approach. 
The CAUTI team has shown to help foster knowledge, integrity in following protocol bundle, and provided real-time education as needed. In the United States, urinary tract infections account for the highest percentage in HAIs and are preventable. The process for CAUTI prevention and reduction has proven to be successful. Additionally, changing the culture of an organization and improving collaboration was paramount to the success of CAUTI reduction. 


\section{References}

AHRQ. (2019). Toolkit for Reducing Catheter-Associated Urinary Tract Infections in Hospital Units: Implementation Guide. Reducing CAUTI in Hospitals. Retrieved from https://www.ahrq.gov/hai/cauti-tools/impl-guide/implementation-guide-appendix-c.html

Al-Kuwaiti, A., Homa, K., \& Maruthamuthu, T. (2016). A New Performance Improvement Model: Adding Benchmarking to the Analysis of Performance Indicator Data. The Joint Commission Journal on Quality and Patient Safety, 42(10), 462-465. doi:10.1016/S1553$7250(16) 42062-3$

Benedicto, A. M. (2017). Engaging All Employees in Efforts to Achieve High Reliability. Frontier Health Service Management, 33(4), 33-40. doi:10.1097/HAP.0000000000000011

Berman, L., Raval, M. V., \& Goldin, A. (2018). Process improvement strategies: Designing and implementing quality improvement research. Seminal Pediatriac Surgery, 27(6), 379385. doi:10.1053/j.sempedsurg.2018.10.006

Bernstein, M., Hou, J. K., Weizman, A. V., Mosko, J., Bollegala, N., Brahmania, M., . . Bell, C. M. (2016). Quality Improvement Primer Series: How to Sustain a Quality Improvement Effort. Clinical Gastroenterology and Hepatology, 14(10), 1371-1375. doi:10.1016/j.cgh.2016.05.019

Boettcher, P., Hunter, R., \& McGonagle, P. (2019). Using Lean Principles of Standard Work to Improve Clinical Nursing Performance. Nursing Economic\$, 37(3), 152-163.

Carter, N. M., Beitmeier, L., \& Goodloe, L. R. (2014). An Evidence-Based Approach to the Prevention of Catheter-Associated Urinary Track Infections. Urologic Nursing, 34(5). doi:10.7257/1053-816x.2014.34.5.238 
Cherrafi, A., Elfezazi, S., Govindan, K., Garza-Reyes, J. A., Benhida, K., \& Mokhlis, A. (2017). A framework for the integration of Green and Lean Six Sigma for superior sustainability performance. International Journal of Production Research, 55(15), 4481-4515. doi:10.1080/00207543.2016.1266406

Christophersen, K. (2018). Hospital Overview [PowerPoint Presentation]. Fountain Valley Regional Hospital

D'Andreamatteo, A., Ianni, L., Lega, F., \& Sargiacomo, M. (2015). Lean in healthcare: A comprehensive review. Health Policy, 119(9), 1197-1209. doi:10.1016/j.healthpol.2015.02.002

Dascomb, K., Taylor, C. W., Sumner, S., Fetzer, A., Orton, J., Barton, N., . . . Burke, J. P. (2016). Impact of Catheter-Day Reductions on Catheter-Associated Urinary Tract Infection Intervention Evaluation. Paper presented at the Open Forum Infectious Diseases.

de Freitas, J. G., Costa, H. G., \& Ferraz, F. T. (2017). Impacts of Lean Six Sigma over organizational sustainability: A survey study. Journal of Cleaner Production, 156, 262275. doi:10.1016/j.jclepro.2017.04.054

Dumont, C., \& Wakeman, J. (2010, December). Preventing catheter-associated UTIs: Survey Report. Nursing2010, 30.

Durant. (2017). Nurse-driven protocols and the prevention of catheter-associated urinary tract infections: a systematic review. American Journal of Infection Control, 45(12), 13311341. 
Fakih, M. G., Gould, C. V., Trautner, B. W., Meddings, J., Olmsted, R. N., Krein, S. L., \& Saint, S. (2016). Beyond infection: device utilization ratio as a performance measure for urinary catheter harm. Infection Control \& Hospital Epidemiology, 37(3), 327-333.

Fakih, M. G., Krein, S. L., Edson, B., Watson, S. R., Battles, J. B., \& Saint, S. (2014). Engaging health care workers to prevent catheter-associated urinary tract infection and avert patient harm. American Journal of Infection Control, 42(10), S223-S229.

Fasugba, O., Cheng, A. C., Russo, P. L., Northcote, M., Rosebrock, H., \& Mitchell, B. G. (2018). Reducing urinary catheter use: a protocol for a mixed methods evaluation of an electronic reminder system in hospitalised patients in Australia. BMJ Open, 8(5), $\mathrm{e} 020469$.

Felix, K. (2014). APIC CAUTI update 2014. Guide to Preventing Catheter-Associated Urinary Tract Infections. Retrieved from

Ferguson, A. (2018). Implementing a CAUTI Prevention Program in an Acute Care Hospital Setting. Urologic Nursing, 38(6), 273-302.

Field, A. (2018). Discovering Statistics Using IBM SPSS Statistics (5th ed.). Thousand Oaks, CA.: SAGE.

Galiczewski. (2016). Interventions for the prevention of catheter associated urinary tract infections in intensive care units: an integrative review. Intensive and Critical Care Nursing, 32, 1-11.

Galiczewski, \& Shurpin, K. M. (2017). An intervention to improve the catheter associated urinary tract infection rate in a medical intensive care unit: Direct observation of catheter insertion procedure. Intensive Critical Care Nursing, 40, 26-34.

doi:10.1016/j.iccn.2016.12.003 
Gershengorn, H. B., Kocher, R., \& Factor, P. (2014a). Management strategies to effect change in intensive care units: lessons from the world of business. Part I. Targeting quality improvement initiatives. Annals of American Thoracic Society, 11(2), 264-269. doi:10.1513/AnnalsATS.201306-177AS

Gershengorn, H. B., Kocher, R., \& Factor, P. (2014b). Management strategies to effect change in intensive care units: lessons from the world of business. Part II. Quality-improvement strategies. Annals of American Thoracic Society, 11(3), 444-453. doi:10.1513/AnnalsATS.201311-392AS

Gesmundo, M. (2016). Enhancing Nurses’ Knowledge on Catheter-Associated Urinary Tract Infection (CAUTI) Prevention. Kai Tiaki Nursing Research, 7(1), 32-40.

Gould, Gaze, S., Drey, N., \& Cooper, T. (2017). Implementing clinical guidelines to prevent catheter-associated urinary tract infections and improve catheter care in nursing homes: Systematic review. American Journal of Infection Control, 45(5), 471-476.

Gould, Umscheid, C., Agarwal, R., Kuntz, G., \& Pegues, D. (2019). Guideline For Prevention Of Catheter Associated Urinary Tract Infections 2009. Atlanta, GA: Centers for Disease Control and Prevenetion.

Gray, M., Skinner, C., \& Kaler, W. (2016). External Collection Devices as an Alternative to the Indwelling Urinary Catheter: Evidence-Based Review and Expert Clinical Panel Deliberations. Journal of Wound Ostomy Continence Nursing, 43(3), 301-307. doi:10.1097/WON.0000000000000220

Hollenbeak, C. S., \& Schilling, A. L. (2018). The attributable cost of catheter-associated urinary tract infections in the United States: A systematic review. American Journal of Infection Control, 46(7), 751-757. 
Jackson, E., Greene, K., Wyman, A., Patton, S., Prieto, I., \& Bassaly, R. (2018). 44: Risk factors for catheter associated urinary tract infections and catheter associated pain in women with voiding dysfunction following pelvic reconstructive surgery: A retrospective case-control study. American Journal of Obstetrics \& Gynecology, 218(2), S921-S922.

Jain, M., Dogra, V., Mishra, B., Thakur, A., \& Loomba, P. S. (2015). Knowledge and attitude of doctors and nurses regarding indication for catheterization and prevention of catheterassociated urinary tract infection in a tertiary care hospital. Indian journal of critical care medicine: peer-reviewed, official publication of Indian Society of Critical Care Medicine, 19(2), 76 .

John, S., Thomas, M., Cardona, M., Santarina, S. A., Iacono, L., Scanlon, K., \& Woolforde, L. (2015). Staff nurses eliminated catheter-associated urinary tract infections in a neurosurgical intensive care unit. The Journal of Continuing Education in Nursing, 46(9), 384-386.

Jones, L. F., Meyrick, J., Bath, J., Dunham, O., \& McNulty, C. A. M. (2019). Effectiveness of behavioural interventions to reduce urinary tract infections and Escherichia coli bacteraemia for older adults across all care settings: a systematic review. Journal of Hospital Infection, 102(2), 200-218. doi:10.1016/j.jhin.2018.10.013

Kachare, S. D., Sanders, C., Myatt, K., Fitzgerald, T. L., \& Zervos, E. E. (2014). Toward eliminating catheter-associated urinary tract infections in an academic health center. Journal of Surgical Research, 192(2), 280-285.

Kogon, K., Blakemore, S., \& Wood, J. (2015). Project Management for the Unofficial Project Manager (D. Harmsen Ed.). Dallas, Tx.: BenBella Books. 
Körner, M., Wirtz, M. A., Bengel, J., \& Göritz, A. S. (2015). Relationship of organizational culture, teamwork and job satisfaction in interprofessional teams. BMC health services research, 15(1). doi:10.1186/s12913-015-0888-y

Kotter, J. (2019). Together, so much is possible. . Kotter. Retrieved from https://www.kotterinc.com/

Kubiak, T. M., \& Benbow, D. W. (2017). The Certified Six Sigma Black Belt Handbook (3rd ed.). Milwaukee, WI: ASQ Quality Press.

Kuwaiti, A. A., \& Subbarayalu, A. V. (2017). Reducing Hospital-acquired Infection Rate using the Six Sigma DMAIC Approach. Saudi Journal of Medicine \& Medical Science, 5(3), 260-266. doi:10.4103/sjmms.sjmms_98_16

Leapfrog Hospital Ratings. (2018). Retrieved from

Letica-Kriegel, A. S., Salmasian, H., Vawdrey, D. K., Youngerman, B. E., Green, R. A., Furuya, E. Y., . . Perotte, R. (2019). Identifying the risk factors for catheter-associated urinary tract infections: a large cross-sectional study of six hospitals. BMJ Open, 9(2), e022137. doi:10.1136/bmjopen-2018-022137

Lo, E., Nicolle, L. E., Coffin, S. E., Gould, C., Maragakis, L. L., Meddings, J., . . Yokoe, D. S. (2014). Strategies to prevent catheter-associated urinary tract infections in acute care hospitals: 2014 update. Infection Control \& Hospital Epidemiology, 35(5), 464-479.

Makic, M. B. F., \& Wald, H. (2017). Achieving improved patient outcomes through interprofessional teams. Journal of Interprofessional Education \& Practice, 8, 91-94. doi:10.1016/j.xjep.2017.07.003 
Maxwell, J. C. (2015). 4 Leadership styles to help you get the most out of your team. Retrieved from http://www.johnmaxwell.com/blog/4-leadership-styles-that-trigger-peakperformance

Maxwell, J. C. (2016). The 5 levels of leadership. Retrieved from http://www.johnmaxwell.com/blog/5-levels-of-leadership

Menegueti, M. G., Ciol, M. A., Bellissimo-Rodrigues, F., Auxiliadora-Martins, M., Gaspar, G. G., da Silva Canini, S. R. M., . . Laus, A. M. (2019). Long-term prevention of catheterassociated urinary tract infections among critically ill patients through the implementation of an educational program and a daily checklist for maintenance of indwelling urinary catheters: A quasi-experimental study. Medicine, 98(8).

Mitchell, G. (2013). Selecting the best theory to implement planned change. Nursing Management, 20(1).

Mizerek, E., \& Wolf, L. (2015). To Foley or Not To Foley: Emergency Nurses' Perceptions of Clinical Decision Making in the Use of Urinary Catheters in the Emergency Department. J Emerg Nurs, 41(4), 329-334. doi:10.1016/j.jen.2014.09.009

Mohammed, H. T., \& Hamza, R. A. H. (2019). Effectiveness of Educational Program on Nurses' Knowledge toward Preventing Female Catheter-Associated Urinary Tract Infections Indian Journal of Forensic Medicine \& Toxicology, 13(1), 237-242.

Moran, K., Burson, R., \& Conrad, D. (2020). The Doctor of Nursing Practice Project A Framework for Success (3rd. ed.). Burlington, MA.: Jones \& Bartlett Learning. Murphy, C., Prieto, J., \& Fader, M. (2015). "It's easier to stick a tube in": a qualitative study to understand clinicians' individual decisions to place urinary catheters in acute medical care. BMJ Quality \& Safety, 24(7), 444-450. doi:10.1136/bmjqs-2015-004114 
National Healthcare Safety Network SIR for CAUTI Data for Hospital Inpatient Quality

Reporting. (2017). Retrieved from Centers for Disease Control and Prevention: https://nhsn2.cdc.gov/ps/runRequestAnalysisReport.action

NHSN. (2019). The NHSN Standardized Infection Ratio (SIR). Atlanta, GA: U.S. Department of Health \& Human Services Retrieved from https://www.cdc.gov/nhsn/pdfs/ps-analysisresources/nhsn-sir-guide.pdf.

Nordin, N., \& Deros, B. M. (2017). Organisational change framework for lean manufacturing implementation. International Journal of Supply Chain Management, 6(3), 309-320.

Padula, W. V., Duffy, M. P., Yilmaz, T., \& Mishra, M. K. (2014). Integrating systems engineering practice with health-care delivery. Health Systems, 3(3), 159-164.

Parker, V., Giles, M., Graham, L., Suthers, B., Watts, W., O’Brien, T., \& Searles, A. (2017). Avoiding inappropriate urinary catheter use and catheter-associated urinary tract infection (CAUTI): a pre-post control intervention study. BMC health services research, 17(1). doi:10.1186/s12913-017-2268-2

Peate, I., \& Gil, M. (2015). Catheter care: helping reduce the risk of infection British Journal of Healthcare Assistants, 09(1), 26-29.

Quality Measures. (2018). Baltimore, MD: Federal Government Retrieved from https://www.cms.gov/Medicare/Quality-Initiatives-Patient-AssessmentInstruments/QualityMeasures/index.html.

Regagnin, D. A., da Silva Alves, D. S., Cavalheiro, A. M., Camargo, T. Z. S., Marra, A. R., da Silva Victor, E., \& Edmond, M. B. (2016). Sustainability of a program for continuous reduction of catheter-associated urinary tract infection. American Journal of Infection Control, 44(6), 642-646. 
Rhee, C., Phelps, M. E., Meyer, B., \& Reed, W. G. (2016). Viewing prevention of catheterassociated urinary tract infection as a system: using systems engineering and human factors engineering in a quality improvement project in an Academic Medical Center. The Joint Commission Journal on Quality and Patient Safety, 42(10), 447-AP410.

Rozario, D. (2018). Reducing catheter-associated urinary tract infections using a multimodal approach — the NSQIP experience of Oakville Trafalgar Memorial Hospital. Canadian Journal of Surgery, 61(4), E7.

Saint, S., Fowler, K. E., Sermak, K., Gaies, E., Harrod, M., Holland, P., . . Krein, S. L. (2015). Introducing the No Preventable Harms campaign: creating the safest health care system in the world, starting with catheter-associated urinary tract infection prevention. American Journal of Infection Control, 43(3), 254-259.

Sampathkumar, P., Barth, J. W., Johnson, M., Marosek, N., Johnson, M., Worden, W., . . . Dhanorker, S. (2016). Mayo Clinic reduces catheter-associated urinary tract infections through a bundled 6-C approach. The Joint Commission Journal on Quality and Patient Safety, 42(6), 254-AP254.

Scanlon, K. A., Wells, C. M., Woolforde, L., Khameraj, A., \& Baumgarten, J. (2017). Saving lives and reducing harm: A CAUTI reduction program. Nursing Economics, 35(3), 134. Science of Improvement: Establishing Measures. (2020). How to Improve. Retrieved from http://www.ihi.org/resources/Pages/HowtoImprove/ScienceofImprovementEstablishingM easures.aspx

Shaver, B., Eyerly-Webb, S. A., Gibney, Z., Silverman, L., Pineda, C., \& Solomon, R. J. (2018). Trauma and intensive care nursing knowledge and attitude of Foley catheter insertion and maintenance. Journal of Trauma Nursing, 25(1), 66-72. 
Shrivastava, S. R., \& Shrivastava, P. S. (2019). The need for a balanced scorecard to monitor hospital performance. Acta Medica International, 6(2), 99.

Smith, C. (2015). On the road to zero CAUTIs: Reducing urinary catheter device days. American Nurse Today, 10(1), 46-48.

Sreeramoju, P. (2019). Reducing Infections “Together”: A Review of Socioadaptive Approaches. Open Forum Infectious Diseases, 6(2). doi:10.1093/ofid/ofy348

Taha, H., Raji, S. J., Khallaf, A., Abu Hija, S., Mathew, R., Rashed, H., . . Ellahham, S. (2017). Improving Catheter Associated Urinary Tract Infection Rates in the Medical Units. BMJ Quality Improvement Reports, 6(1), u209593.w207966.

doi:10.1136/bmjquality.u209593.w7966

Tyagi, A., \& Singh, P. (2019). Hospital performance management: a multi-criteria decisionmaking approach. International Journal of Healthcare Management, 12(4), 286-291.

Zorich, K. (2018). Foley Champions. Prevention of CAUTI. Fountain Valley Regional Medical Center. 


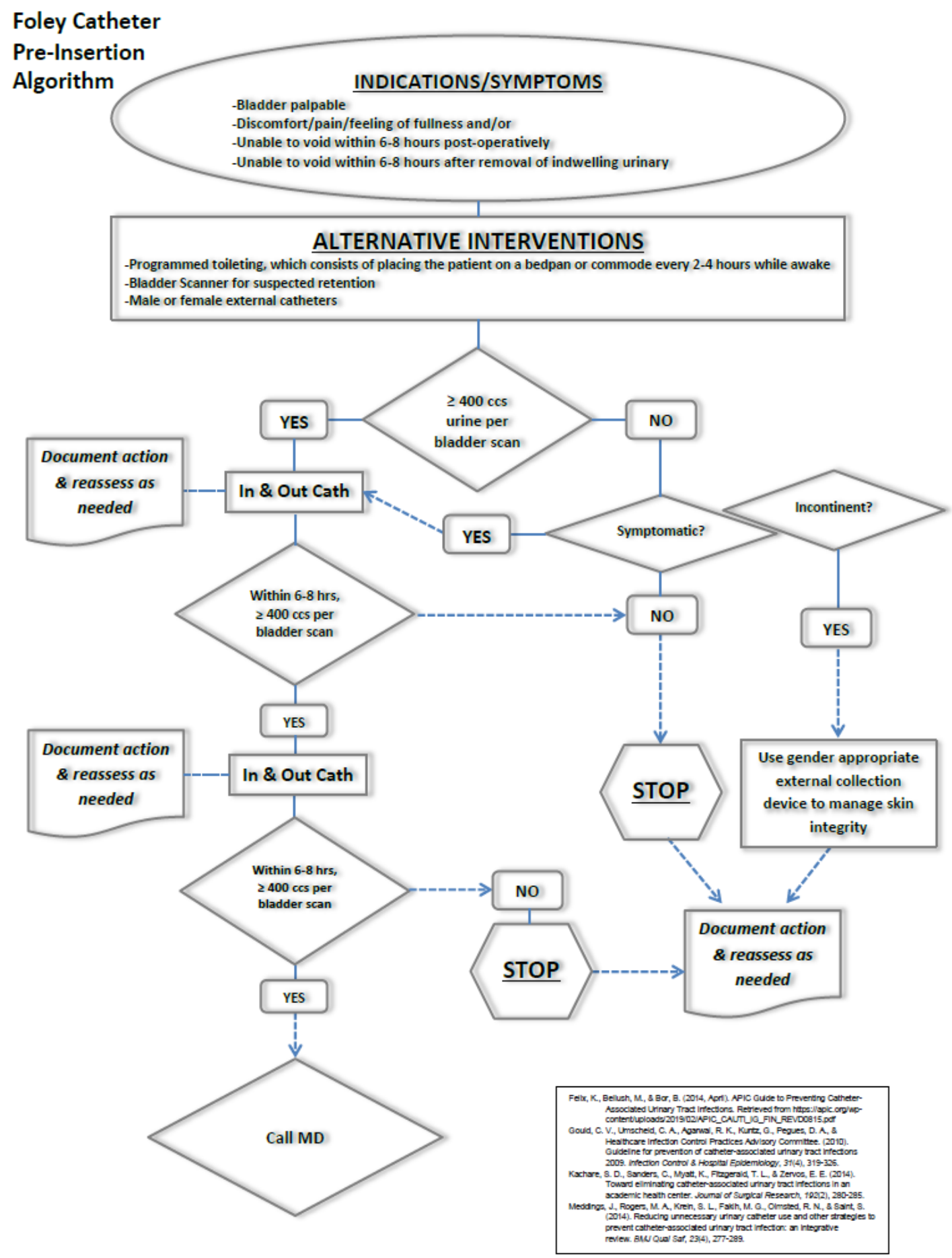

Figure 1. Pre-Insertion Algorithm 


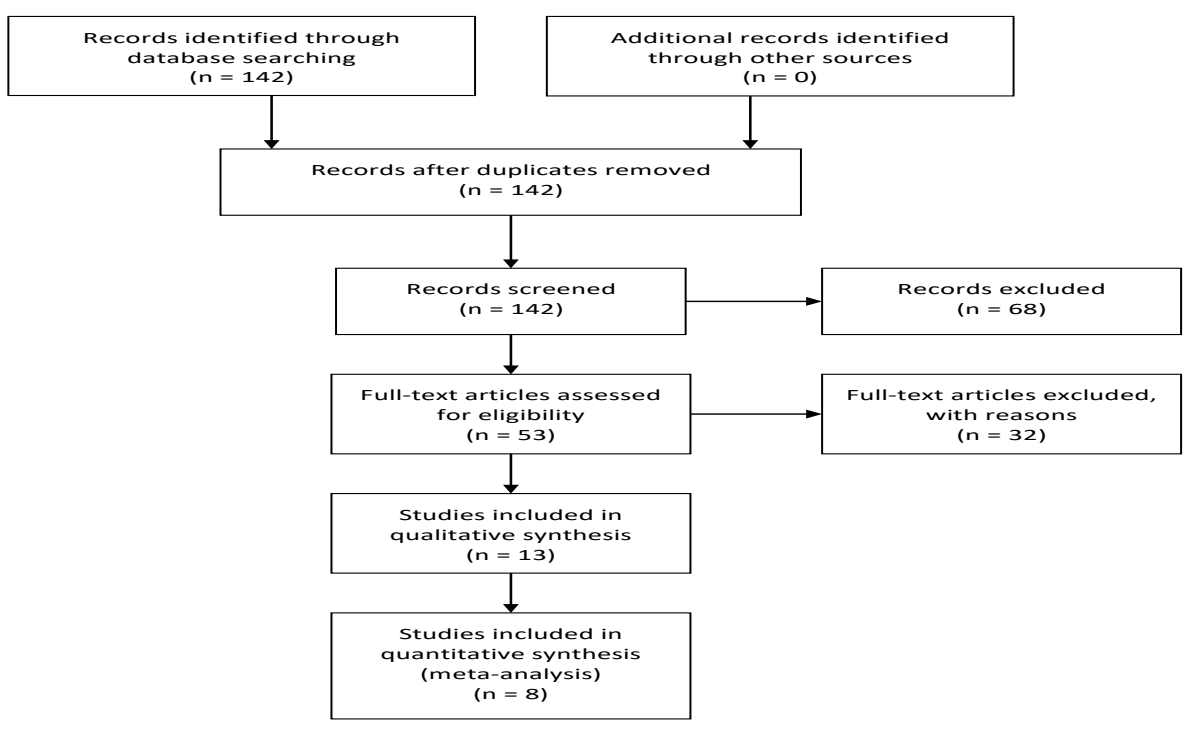

Figure 2. PRISMA flow diagram showing inclusion and exclusion criteria of research. 


\begin{tabular}{|c|c|}
\hline Internal Forces (Project) & External Forces (Organizational) \\
\hline Strengths & Opportunities \\
\hline $\begin{array}{l}\text { Support from organization } \\
\text { Employees eager to help } \\
\text { Materials already in place (CHG, Purewick, condom } \\
\text { catheter, etc.) } \\
\text { Education support in place } \\
\text { Physicians bought in to the goal } \\
\text { Nurse driven protocol already in place }\end{array}$ & $\begin{array}{l}\text { Hospitals with low rates around us and can share } \\
\text { practices } \\
\text { Literature readily available on best practices } \\
\text { Support from vendors of the materials for } \\
\text { educational purposes }\end{array}$ \\
\hline Weaknesses & Threats \\
\hline $\begin{array}{l}\text { Below national benchmark } \\
\text { Patients' lives at risk } \\
\text { Increase patient LOS } \\
\text { Financial burden } \\
\text { Stressors for patients/families } \\
\text { Nursing staff not following the protocol } \\
\text { Physician buy in } \\
\text { Supply stock in each nursing department }\end{array}$ & $\begin{array}{l}\text { Patients choosing other facilities for care due to our } \\
\text { high rates } \\
\text { Low CMS star ratings which are published for the } \\
\text { public } \\
\text { Reputational harm due to high rates and published } \\
\text { hospital acquired infection rates }\end{array}$ \\
\hline
\end{tabular}

Figure 3. SWOT Analysis 


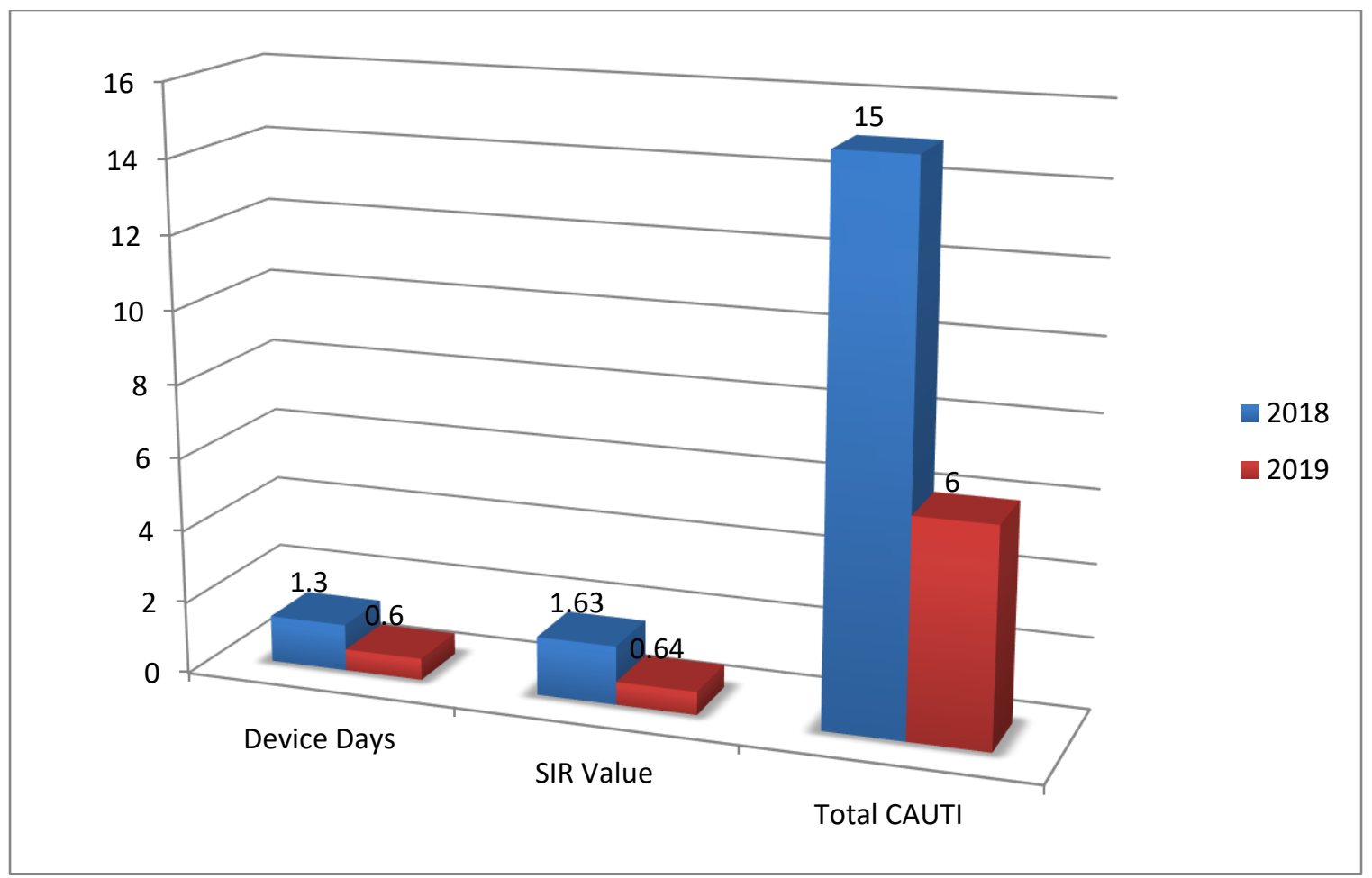

Figure 4. Device days, SIR values, and total CAUTI for 2018 \& 2019. 


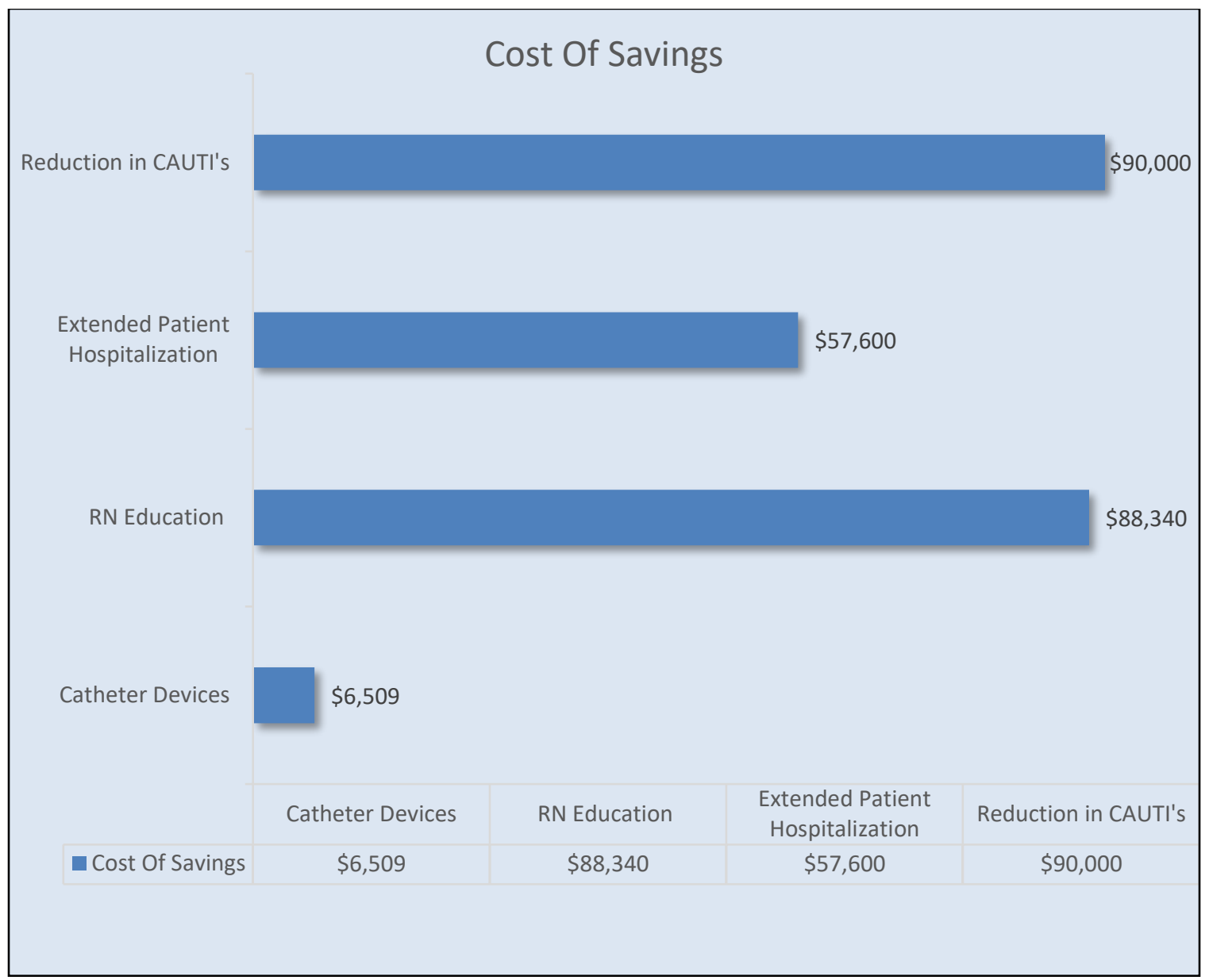

Figure 5. Cost of savings 


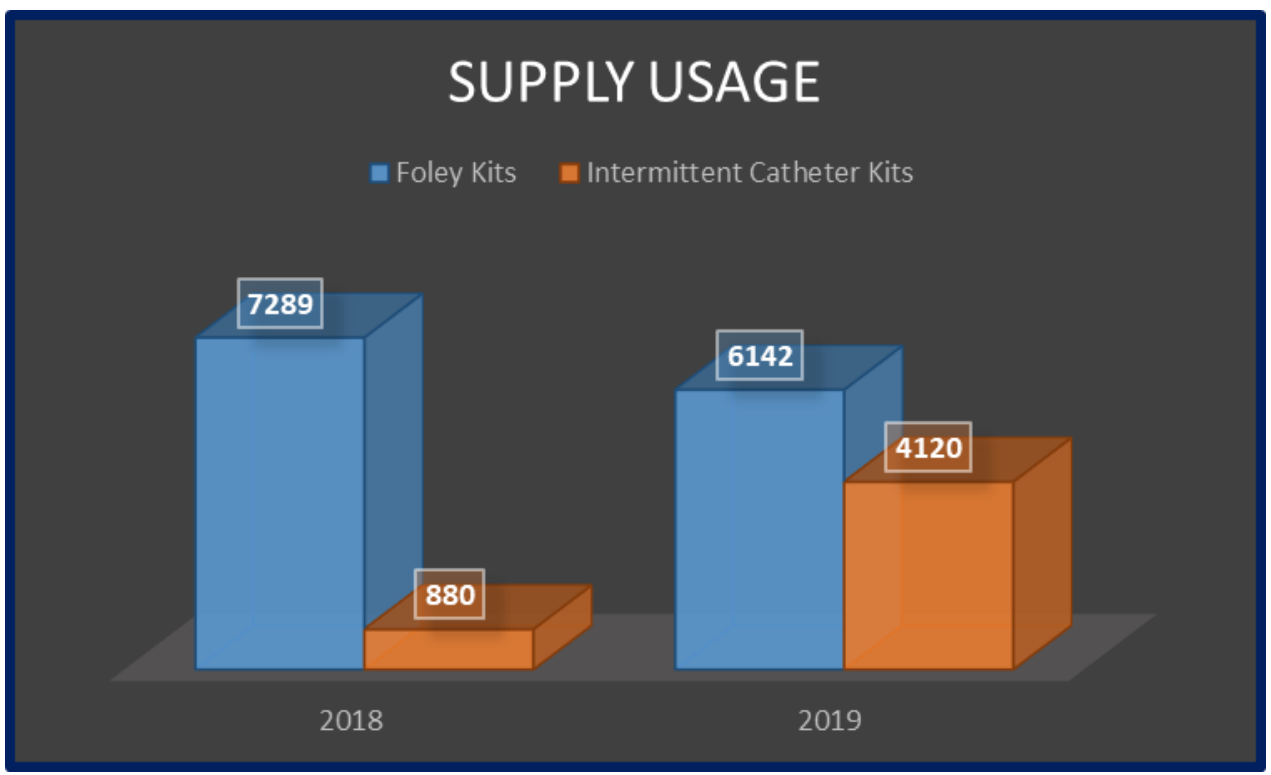

Figure 6. Supply usage of urinary indwelling catheter kits and intermittent catheter kits. 
Appendix A

Summary of Primary Research Evidence

\begin{tabular}{|c|c|c|c|c|c|c|}
\hline Citation & $\begin{array}{c}\text { Sample } \\
\text { Sample size }\end{array}$ & $\begin{array}{c}\text { Design, } \\
\text { Level, } \\
\text { \& Quality } \\
\text { Grade }\end{array}$ & $\begin{array}{l}\text { Intervention } \\
\qquad \text { \& } \\
\text { Comparison } \\
\text { Definitions } \\
\text { (Include any } \\
\text { specific } \\
\text { research } \\
\text { tools used } \\
\text { along with } \\
\text { reliability \& } \\
\text { validity) }\end{array}$ & $\begin{array}{l}\text { Theoretical } \\
\text { Foundation }\end{array}$ & $\begin{array}{l}\text { Outcome } \\
\text { Definition }\end{array}$ & Results - Key Findings \\
\hline $\begin{array}{l}\text { Rhee, C., Phelps, M. E., Meyer, B., \& } \\
\text { Reed, W. G. (2016). Viewing } \\
\text { prevention of catheter-associated } \\
\text { urinary tract infection as a system: } \\
\text { using systems engineering and human } \\
\text { factors engineering in a quality } \\
\text { improvement project in an Academic } \\
\text { Medical Center. The Joint } \\
\text { Commission Journal on Quality and } \\
\text { Patient Safety, 42(10), 447-AP410. }\end{array}$ & $\begin{array}{c}\text { 2011-2012 } \\
\text { Two Hospitals }\end{array}$ & $\begin{array}{l}\text { Qualitative } \\
\text { II/A }\end{array}$ & $\begin{array}{l}\text { Use systems } \\
\text { engineering } \\
\text { and human } \\
\text { factors in } \\
\text { quality } \\
\text { improvement } \\
\text { projects. } \\
\text { DMAIC } \\
\text { process: } \\
\text { project charter, } \\
\text { project team, } \\
\text { VOC, current } \\
\text { state process } \\
\text { map. ID key } \\
\text { outcome, } \\
\text { process and } \\
\text { balancing } \\
\text { measures, data } \\
\text { collection, } \\
\text { detailed } \\
\text { process maps. } \\
\text { Driver } \\
\text { diagrams, } 5 \\
\text { Whys, } \\
\text { Fishbone } \\
\text { diagram, } \\
\text { Pareto }\end{array}$ & $\begin{array}{c}\text { Lean } \\
\text { Six } \\
\text { Sigma/DMAIC }\end{array}$ & $\begin{array}{l}\text { To reduce } \\
\text { CAUTI by } \\
\text { implementing } \\
\text { DMAIC }\end{array}$ & $\begin{array}{l}\text { Decreased CAUTI and decreased cost to the } \\
\text { organization by implementation of Lean Six } \\
\text { Sigma/DMAIC methodologies. }\end{array}$ \\
\hline
\end{tabular}




\begin{tabular}{|c|c|c|c|c|c|c|}
\hline & & & $\begin{array}{l}\text { analysis, } \\
\text { RCA's and } \\
\text { FMEA. PDSA } \\
\text { pilots tested, } \\
\text { future state } \\
\text { process map. }\end{array}$ & & & \\
\hline $\begin{array}{l}\text { Gershengorn, H. B., Kocher, R., \& } \\
\text { Factor, P. (2014). Management } \\
\text { strategies to effect change in intensive } \\
\text { care units: lessons from the world of } \\
\text { business. Part I. Targeting quality } \\
\text { improvement initiatives. Ann Am } \\
\text { Thorac Soc, 11(2), 264-269. } \\
\text { doi:10.1513/AnnalsATS.201306- } \\
\text { 177AS }\end{array}$ & $\begin{array}{l}\text { Four different } \\
\text { QI processes }\end{array}$ & $\begin{array}{l}\text { Meta- } \\
\text { Analysis } \\
\text { III/A }\end{array}$ & $\begin{array}{l}\text { 80/20 rule, } \\
\text { Pareto chart, } \\
\text { RCAa, } \\
\text { Benchmarking, } \\
\text { Failure Mode } \\
\text { and Effects } \\
\text { Analysis }\end{array}$ & $\begin{array}{l}\text { Portions of Lean } \\
\text { Six Sigma }\end{array}$ & $\begin{array}{l}\text { Implement } \\
\text { selected } \\
\text { business } \\
\text { strategies to } \\
\text { improve } \\
\text { quality and } \\
\text { patient safety } \\
\text { in ICU } \\
\text { settings. }\end{array}$ & $\begin{array}{l}\text { Prioritized tools needed to implement } \\
\text { quality improvement initiatives in the ICU } \\
\text { setting. }\end{array}$ \\
\hline $\begin{array}{l}\text { Makic, M. B. F., \& Wald, H. (2017). } \\
\text { Achieving improved patient outcomes } \\
\text { through interprofessional teams. } \\
\text { Journal of Interprofessional Education } \\
\text { \& Practice, } 8,91-94 \text {. } \\
\text { doi:10.1016/j.xjep.2017.07.003 }\end{array}$ & $\begin{array}{l}400 \text { bed } \\
\text { Hospital }\end{array}$ & $\begin{array}{l}\text { Qualitative } \\
\text { II/A }\end{array}$ & $\begin{array}{l}\text { Project } \\
\text { Proposal } \\
\text { FMEA } \\
\text { Lean Six } \\
\text { Sigma tools }\end{array}$ & $\begin{array}{l}\text { Lean } \\
\text { Six Sigma } \\
\text { IHI Model for } \\
\text { Improvement }\end{array}$ & $\begin{array}{l}\text { Improving } \\
\text { outcomes } \\
\text { through } \\
\text { effective } \\
\text { processes via } \\
\text { teams }\end{array}$ & $\begin{array}{l}\text { Success in improving outcomes through } \\
\text { effective processes via teams }\end{array}$ \\
\hline $\begin{array}{l}\text { Kuwaiti, A. A., \& Subbarayalu, A. V. } \\
\text { (2017). Reducing Hospital-acquired } \\
\text { Infection Rate using the Six Sigma } \\
\text { DMAIC Approach. Saudi J Med Med } \\
\text { Sci, 5(3), 260-266. } \\
\text { doi:10.4103/sjmms.sjmms_98_16 }\end{array}$ & $\begin{array}{c}\text { 2013-2014 } \\
\text { Hospital }\end{array}$ & $\begin{array}{l}\text { Prospective } \\
\text { III/A }\end{array}$ & $\begin{array}{l}\text { DMAIC } \\
\text { Process }\end{array}$ & $\begin{array}{l}\text { Six Sigma } \\
\text { DMAIC }\end{array}$ & $\begin{array}{l}\text { Study the } \\
\text { effect of the } \\
\text { Six Sigma } \\
\text { DMAIC } \\
\text { approach in } \\
\text { reducing the } \\
\text { HAI rates }\end{array}$ & $\begin{array}{l}\text { Results show that the DMAIC approach is } \\
\text { effective in reducing HAI rates. }\end{array}$ \\
\hline $\begin{array}{l}\text { Benedicto, A. M. (2017). Engaging } \\
\text { All Employees in Efforts to Achieve } \\
\text { High Reliability. Front Health Serv } \\
\text { Manage, 33(4), 33-40. } \\
\text { doi:10.1097/HAP.0000000000000011 }\end{array}$ & Healthcare & $\begin{array}{l}\text { Quality } \\
\text { Improvement } \\
\text { V/A }\end{array}$ & $\begin{array}{l}\text { High } \\
\text { Reliability } \\
\text { Healthcare } \\
\text { Maturity } \\
\text { Model }\end{array}$ & $\begin{array}{c}\text { Lean } \\
\text { Six Sigma }\end{array}$ & $\begin{array}{l}\text { Engaging staff } \\
\text { in efforts to } \\
\text { learn LSS } \\
\text { methodologies }\end{array}$ & $\begin{array}{l}\text { Implementation of these methods have } \\
\text { shown to prevent harm and promote a safe } \\
\text { work environment. }\end{array}$ \\
\hline $\begin{array}{l}\text { Boettcher, P., Hunter, R., \& } \\
\text { McGonagle, P. (2019). Using Lean } \\
\text { Principles of Standard Work to } \\
\text { Improve Clinical Nursing } \\
\text { Performance. Nursing Economic\$, } \\
\text { 37(3), 152-163. }\end{array}$ & $\begin{array}{l}113 \text { bed } \\
\text { Hospital }\end{array}$ & $\begin{array}{l}\text { Meta- } \\
\text { Analysis } \\
\text { III/A }\end{array}$ & $\begin{array}{c}\text { PDSA } \\
\text { Lewin's } \\
\text { Change Model } \\
\text { Mentorship } \\
\text { Tool } \\
\text { Lean Tools } \\
\end{array}$ & Lean & $\begin{array}{l}\text { Using Lean to } \\
\text { improve } \\
\text { clinical nursing } \\
\text { performance }\end{array}$ & $\begin{array}{c}\text { Tools used by nurses decreased negative } \\
\text { outcomes }\end{array}$ \\
\hline $\begin{array}{l}\text { Al-Kuwaiti, A., Homa, K., \& } \\
\text { Maruthamuthu, T. (2016). A New } \\
\text { Performance Improvement Model: } \\
\text { Adding Benchmarking to the Analysis }\end{array}$ & $\begin{array}{c}\text { 2013-2014 } \\
\text { Hospital }\end{array}$ & $\begin{array}{l}\text { Qualitative } \\
\text { II/A }\end{array}$ & $\begin{array}{c}\text { DMAIC } \\
\text { Benchmark } \\
\text { Control Charts }\end{array}$ & Six Sigma & $\begin{array}{l}\text { Implement } \\
\text { benchmarking } \\
\text { to the analysis } \\
\text { of performance }\end{array}$ & $\begin{array}{l}\text { Using DMAIC model was successful by } \\
\text { variable reduction }\end{array}$ \\
\hline
\end{tabular}




\begin{tabular}{|c|c|c|c|c|c|c|}
\hline $\begin{array}{l}\text { of Performance Indicator Data. The } \\
\text { Joint Commission Journal on Quality } \\
\text { and Patient Safety, 42(10), 462-465. } \\
\text { doi:10.1016/S1553-7250(16)42062-3 }\end{array}$ & & & & & $\begin{array}{l}\text { improvement } \\
\text { data }\end{array}$ & \\
\hline $\begin{array}{l}\text { Padula, W. V., Duffy, M. P., Yilmaz, } \\
\text { T., \& Mishra, M. K. (2014). } \\
\text { Integrating systems engineering } \\
\text { practice with health-care delivery. } \\
\text { Health Systems, 3(3), 159-164. }\end{array}$ & 9 Articles & $\begin{array}{l}\text { Prospective } \\
\text { Cohort Study } \\
\text { II/A }\end{array}$ & $\begin{array}{l}\text { PDSA } \\
\text { SBAR } \\
\text { Mapping } \\
\text { Processes } \\
\text { Workflow } \\
\text { Modeling } \\
\text { SPC Charts }\end{array}$ & $\begin{array}{c}\text { Lean } \\
\text { Six Sigma }\end{array}$ & $\begin{array}{l}\text { Successful } \\
\text { approaches of } \\
\text { systems to } \\
\text { solve problems } \\
\text { of clinical } \\
\text { work-a rounds }\end{array}$ & $\begin{array}{l}\text { Cost-effective return through avoidance of } \\
\text { systematic issues of implementing evidence- } \\
\text { based practice }\end{array}$ \\
\hline $\begin{array}{l}\text { D'Andreamatteo, A., Ianni, L., Lega, } \\
\text { F., \& Sargiacomo, M. (2015). Lean in } \\
\text { healthcare: A comprehensive review. } \\
\text { Health Policy, 119(9), 1197-1209. } \\
\text { doi:10.1016/j.healthpol.2015.02.002 }\end{array}$ & $\begin{array}{l}243 \text { Articles } \\
\text { Healthcare }\end{array}$ & $\begin{array}{l}\text { Qualitative } \\
\text { II/A }\end{array}$ & $\begin{array}{l}\text { Thematic } \\
\text { Analysis } \\
\text { Lean Tools } \\
\text { Control Chart }\end{array}$ & $\begin{array}{c}\text { Lean } \\
\text { Six Sigma }\end{array}$ & $\begin{array}{l}\text { To present a } \\
\text { comp overview } \\
\text { of main issues } \\
\text { with } \\
\text { implementation } \\
\text { of Lean in } \\
\text { healthcare }\end{array}$ & $\begin{array}{l}\text { Still need more research in impacts in } \mathrm{HC} \text {. } \\
\text { Lean is weak in methods. }\end{array}$ \\
\hline $\begin{array}{l}\text { Gershengorn, H. B., Kocher, R., \& } \\
\text { Factor, P. (2014). Management } \\
\text { strategies to effect change in intensive } \\
\text { care units: lessons from the world of } \\
\text { business. Part II. Quality-improvement } \\
\text { strategies. Ann Am Thorac Soc, 11(3), } \\
\text { 444-453. } \\
\text { doi:10.1513/AnnalsATS.201311- } \\
\text { 392AS }\end{array}$ & $\begin{array}{c}6 \\
\text { Methodologies }\end{array}$ & $\begin{array}{l}\text { Meta- } \\
\text { Analysis } \\
\text { II/A }\end{array}$ & $\begin{array}{c}\text { DMAIC } \\
\text { Kaizen } \\
\text { Checklists } \\
\text { Algorithms } \\
\text { Run Chart } \\
\text { Pareto Chart } \\
\text { Waterfall } \\
\text { Chart } \\
\text { Dashboards } \\
\text { Spaghetti } \\
\text { Chart }\end{array}$ & $\begin{array}{c}\text { Lean } \\
\text { Six Sigma }\end{array}$ & $\begin{array}{l}\text { Selection of } \\
\text { various tools to } \\
\text { complete a } \\
\text { quality } \\
\text { improvement } \\
\text { project }\end{array}$ & Successful quality improvement strategies \\
\hline $\begin{array}{l}\text { Gershengorn, H. B., Kocher, R., \& } \\
\text { Factor, P. (2014). Management } \\
\text { strategies to effect change in intensive } \\
\text { care units: lessons from the world of } \\
\text { business. Part III. Effectively effecting } \\
\text { and sustaining change. Ann Am } \\
\text { Thorac Soc, 11(3), 454-457. } \\
\text { doi:10.1513/AnnalsATS.201311- } \\
\text { 393AS }\end{array}$ & $\begin{array}{l}5 \text { Strategies } \\
\text { Hospital }\end{array}$ & $\begin{array}{l}\text { Meta- } \\
\text { Analysis } \\
\text { II/A }\end{array}$ & $\begin{array}{l}\text { Team Building } \\
\text { Coaching } \\
\text { Smashing } \\
\text { Silos } \\
\text { Push-Pull } \\
\text { System }\end{array}$ & $\begin{array}{c}\text { Lean } \\
\text { Six Sigma }\end{array}$ & $\begin{array}{l}\text { Sustainability } \\
\text { of quality } \\
\text { improvement } \\
\text { projects and } \\
\text { tools to use to } \\
\text { accomplish this }\end{array}$ & $\begin{array}{c}\text { Proven methods that sustain quality } \\
\text { improvement projects were implemented } \\
\text { with successful outcomes }\end{array}$ \\
\hline $\begin{array}{l}\text { de Freitas, J. G., Costa, H. G., \& } \\
\text { Ferraz, F. T. (2017). Impacts of Lean } \\
\text { Six Sigma over organizational } \\
\text { sustainability: A survey study. Journal } \\
\text { of Cleaner Production, 156, 262-275. } \\
\text { doi:10.1016/j.jclepro.2017.04.054 }\end{array}$ & $\begin{array}{l}16 \text { Articles } \\
\text { QI }\end{array}$ & $\begin{array}{l}\text { Qualitative } \\
\text { Quantitative }\end{array}$ & $\begin{array}{l}\text { Lean Tools } \\
\text { Six Sigma } \\
\text { Tools } \\
\text { Pie Charts } \\
\text { Pareto Chart }\end{array}$ & $\begin{array}{c}\text { Lean } \\
\text { Six Sigma }\end{array}$ & $\begin{array}{l}\text { Research the } \\
\text { influence of } \\
\text { Lean Six } \\
\text { Sigma over } \\
\text { organizational } \\
\text { sustainability } \\
\end{array}$ & $\begin{array}{l}\text { Cost control was accomplished by using } \\
\text { these methods. Reduce waste, increase } \\
\text { quality service, reduce process variability }\end{array}$ \\
\hline
\end{tabular}




\begin{tabular}{|c|c|c|c|c|c|c|}
\hline $\begin{array}{l}\text { Berman, L., Raval, M. V., \& Goldin, } \\
\text { A. (2018). Process improvement } \\
\text { strategies: Designing and } \\
\text { implementing quality improvement } \\
\text { research. Semin Pediatr Surg, } 27(6) \text {, } \\
\text { 379-385. } \\
\text { doi:10.1053/j.sempedsurg.2018.10.006 }\end{array}$ & $\begin{array}{c}2014-2016 \\
\text { Hospital }\end{array}$ & $\begin{array}{c}\text { Qualitative } \\
\text { II/A }\end{array}$ & $\begin{array}{l}\text { PDSA } \\
\text { Fishbone } \\
\text { Analysis } \\
\text { Key Driver } \\
\text { Diagram } \\
\text { Run Chart }\end{array}$ & $\begin{array}{c}\text { PDSA } \\
\text { Six Sigma }\end{array}$ & $\begin{array}{l}\text { Show quality } \\
\text { improvement } \\
\text { projects } \\
\text { improve pt care } \\
\text { and can be } \\
\text { shared between } \\
\text { institutions }\end{array}$ & $\begin{array}{c}\text { There was successful in sharing with } \\
\text { hospital who don't have many resources. } \\
\text { Other hospitals were able to follow } \\
\text { methodologies. }\end{array}$ \\
\hline
\end{tabular}


Appendix B

Summary of Systematic Reviews

\begin{tabular}{|c|c|c|c|c|c|c|c|}
\hline Citation & Question & Search Strategy & $\begin{array}{l}\text { Inclusion/ } \\
\text { Exclusion Criteria }\end{array}$ & $\begin{array}{l}\text { Data Extraction and } \\
\text { Analysis }\end{array}$ & Key Findings & $\begin{array}{l}\text { Recommendation/ } \\
\text { Implications }\end{array}$ & $\begin{array}{l}\begin{array}{l}\text { Level of } \\
\text { Evidence }\end{array} \\
\end{array}$ \\
\hline $\begin{array}{l}\text { Scanlon, K. A., } \\
\text { Wells, C. M., } \\
\text { Woolforde, L., } \\
\text { Khameraj, A., \& } \\
\text { Baumgarten, J. } \\
\text { (2017). Saving lives } \\
\text { and reducing } \\
\text { harm: A CAUTI } \\
\text { reduction } \\
\text { program. Nursing } \\
\text { Economics, 35(3), } \\
134 .\end{array}$ & \begin{tabular}{|l|} 
The purpose of \\
this quality \\
improvement \\
project was to \\
develop a \\
catheter- \\
associated urinary \\
tract infection \\
(CAUTI) reduction \\
program focusing \\
on developing best \\
practices and \\
transferring them \\
across the \\
healthcare \\
organization.
\end{tabular} & $\begin{array}{l}188 \text { nurses } \\
\text { ICU and non-ICU } \\
\text { areas }\end{array}$ & $\begin{array}{l}\text { Is it sustainable. } \\
\text { And Increased } \\
\text { confidence and } \\
\text { teamwork for } \\
\text { staff. }\end{array}$ & & $\begin{array}{l}\text { Decreased CAUTI } \\
\text { by } 81 \% \text { and saved } \\
\$ 75.5 \mathrm{~K} \text { over } 18 \\
\text { months }\end{array}$ & $\begin{array}{l}\text { Increased } \\
\text { confidence and } \\
\text { teamwork for } \\
\text { staff. }\end{array}$ & III/A \\
\hline $\begin{array}{l}\text { Mitchell, B. G., } \\
\text { Northcote, M., } \\
\text { Cheng, A. C., } \\
\text { Fasugba, O., } \\
\text { Russo, P. L., \& } \\
\text { Rosebrock, H. } \\
\text { (2019). Reducing } \\
\text { urinary catheter } \\
\text { use using an } \\
\text { electronic } \\
\text { reminder system } \\
\text { in hospitalized } \\
\text { patients: A }\end{array}$ & $\begin{array}{l}\text { To determine the } \\
\text { effectiveness and } \\
\text { ease of use of an } \\
\text { electronic } \\
\text { reminder device in } \\
\text { reducing urinary } \\
\text { catheterization } \\
\text { duration. }\end{array}$ & \begin{tabular}{||l|} 
3 hospital with \\
\\
1100 beds each. \\
Nurses. ICU setting
\end{tabular} & $\begin{array}{l}\text { l: E:Hosptials } \\
\text { alredy in a study, } \\
\text { or just opening, } \\
\text { closing or } \\
\text { relocating. And } \\
\text { pt's who have } \\
\text { foley from OR. }\end{array}$ & & $\begin{array}{l}\text { The CATH TAG did } \\
\text { not reduce the } \\
\text { duration of } \\
\text { catheterization, } \\
\text { but potential } \\
\text { benefits in } \\
\text { patients outside } \\
\text { the ICU were } \\
\text { identified. } \\
\text { Electronic } \\
\text { reminders may be } \\
\text { useful to aid } \\
\text { prompt removal of }\end{array}$ & $\begin{array}{l}\text { Randomised } \\
\text { control design. } \\
\text { Evalualtion of } \\
\text { effectiveness and } \\
\text { cost-effetiveness. } \\
\text { Limited to } \\
\text { hospitals in high- } \\
\text { income country. }\end{array}$ & I/A \\
\hline
\end{tabular}




\begin{tabular}{|c|c|c|c|c|c|c|c|}
\hline Citation & Question & Search Strategy & $\begin{array}{l}\text { Inclusion/ } \\
\text { Exclusion Criteria }\end{array}$ & $\begin{array}{l}\text { Data Extraction and } \\
\text { Analysis }\end{array}$ & Key Findings & $\begin{array}{l}\text { Recommendation/ } \\
\text { Implications }\end{array}$ & $\begin{array}{l}\begin{array}{l}\text { Level of } \\
\text { Evidence }\end{array} \\
\end{array}$ \\
\hline $\begin{array}{l}\text { randomized } \\
\text { stepped-wedge } \\
\text { trial. Infection } \\
\text { Control \& Hospital } \\
\text { Epidemiology, } \\
40(4), 427-431 . \\
\text { doi:10.1017/ice.20 } \\
19.31\end{array}$ & & & & & $\begin{array}{l}\text { urinary catheters } \\
\text { in the non-ICU } \\
\text { hospital setting. }\end{array}$ & & \\
\hline $\begin{array}{l}\text { Jones, L. F., } \\
\text { Meyrick, J., Bath, } \\
\text { J., Dunham, O., \& } \\
\text { McNulty, C. A. M. } \\
\text { (2019). } \\
\text { Effectiveness of } \\
\text { behavioral } \\
\text { interventions to } \\
\text { reduce urinary } \\
\text { tract infections } \\
\text { and Escherichia } \\
\text { coli bacteremia for } \\
\text { older adults across } \\
\text { all care settings: a } \\
\text { systematic review. } \\
\text { Journal of Hospital } \\
\text { Infection, 102(2), } \\
200-218 . \\
\text { doi:10.1016/j.jhin. } \\
2018.10 .013\end{array}$ & \begin{tabular}{|l} 
To examine \\
effectiveness of \\
behavioral \\
interventions to \\
reduce E. coli \\
bacteremia \\
and/or \\
symptomatic UTIs \\
for older adults. \\
\end{tabular} & $\begin{array}{l}\text { Urinary tract } \\
\text { infection, E. coli } \\
\text { antimicrobial } \\
\text { resistance, Older } \\
\text { adults, } \\
\text { Interventions, } \\
\text { Systematic review }\end{array}$ & $\begin{array}{l}\text { I: All studies } \\
\text { evaluating } \\
\text { behavioral } \\
\text { interventions to } \\
\text { reduce or prevent } \\
\text { symptomatic UTI } \\
\text { or E. coli } \\
\text { bacteremia, } \\
\text { studies 1990 } \\
\text { onwards, in } \\
\text { English. E: If pt's } \\
\text { ages were not } \\
\text { provided, specialty } \\
\text { hospitals, if } \\
\text { diagnostic } \\
\text { algorithms used, } \\
\text { interventions with } \\
\text { pharmaceuticals. }\end{array}$ & & $\begin{array}{l}\text { Feedback should } \\
\text { be considered } \\
\text { because it } \\
\text { facilitated } \\
\text { reductions in UTI } \\
\text { when used alone } \\
\text { or in multi- } \\
\text { faceted } \\
\text { interventions } \\
\text { including } \\
\text { education, audit } \\
\text { or catheter } \\
\text { removal } \\
\text { protocols. }\end{array}$ & $\begin{array}{l}\text { A limitation of } \\
\text { this review is } \\
\text { that, despite the } \\
\text { broad remit, the } \\
\text { final number of } \\
\text { studies is } \\
\text { relatively low. It } \\
\text { is possible that } \\
\text { more studies with } \\
\text { negative or non- } \\
\text { significant effects } \\
\text { were not } \\
\text { published. }\end{array}$ & III/A \\
\hline $\begin{array}{l}\text { Durant, D. J. } \\
\text { (2017). Nurse- } \\
\text { driven protocols } \\
\text { and the prevention }\end{array}$ & $\begin{array}{l}\text { Review aims to } \\
\text { discover the effect } \\
\text { of nurse driven } \\
\text { protocols on the }\end{array}$ & $\begin{array}{l}\text { Catheter- } \\
\text { associated urinary } \\
\text { tract infection } \\
\text { Nurse-driven }\end{array}$ & $\begin{array}{l}\text { Research articles } \\
\text { published in the } \\
\text { last } 10 \text { years were } \\
\text { included that }\end{array}$ & & $\begin{array}{l}\text { Nurse Driven } \\
\text { Ptotocols appear } \\
\text { to have a positive } \\
\text { impact on the }\end{array}$ & $\begin{array}{l}\text { Many studies has } \\
\text { small sample } \\
\text { sizes; } 124 . \\
\text { Inconsistant }\end{array}$ & I/A \\
\hline
\end{tabular}




\begin{tabular}{|c|c|c|c|c|c|c|c|}
\hline Citation & Question & Search Strategy & $\begin{array}{l}\text { Inclusion/ } \\
\text { Exclusion Criteria }\end{array}$ & $\begin{array}{l}\text { Data Extraction and } \\
\text { Analysis }\end{array}$ & Key Findings & $\begin{array}{l}\text { Recommendation/ } \\
\text { Implications }\end{array}$ & $\begin{array}{l}\text { Level of } \\
\text { Evidence }\end{array}$ \\
\hline $\begin{array}{l}\text { of catheter- } \\
\text { associated urinary } \\
\text { tract infections: a } \\
\text { systematic review. } \\
\text { American Journal } \\
\text { of Infection } \\
\text { Control, 45(12), } \\
1331-1341 .\end{array}$ & $\begin{array}{l}\text { clinical predictors } \\
\text { and prevalence of } \\
\text { CAUTI. }\end{array}$ & $\begin{array}{l}\text { protocol Quality } \\
\text { improvement } \\
\text { Systematic review }\end{array}$ & $\begin{array}{l}\text { studies the impact } \\
\text { of NDP }\end{array}$ & & $\begin{array}{l}\text { clinical predictors } \\
\text { and prevalence of } \\
\text { CAUTI. }\end{array}$ & $\begin{array}{l}\text { measures in } \\
\text { calculations and } \\
\text { non-stand } \\
\text { measures. Time } \\
\text { periods for eval } \\
\text { varied. }\end{array}$ & \\
\hline $\begin{array}{l}\text { Fasugba, O., } \\
\text { Körner, J., } \\
\text { Mitchell, B. G., \& } \\
\text { Gardner, A. (2017). } \\
\text { Systematic review } \\
\text { and meta-analysis } \\
\text { of the } \\
\text { effectiveness of } \\
\text { antiseptic agents } \\
\text { for meatal } \\
\text { cleaning in the } \\
\text { prevention of } \\
\text { catheter- } \\
\text { associated urinary } \\
\text { tract infections. } \\
\text { Journal of Hospital } \\
\text { Infection, } 95(3), \\
233-242 .\end{array}$ & $\begin{array}{l}\text { To undertake a } \\
\text { systematic review } \\
\text { of the literature } \\
\text { and meta-analysis } \\
\text { of studies } \\
\text { investigating the } \\
\text { effectiveness of } \\
\text { antiseptic cleaning } \\
\text { before urinary } \\
\text { catheter insertion } \\
\text { and during } \\
\text { catheter use for } \\
\text { prevention of } \\
\text { CAUTIs. Methods: } \\
\text { Electronic } \\
\text { databases were } \\
\text { searched }\end{array}$ & $\begin{array}{l}\text { Antiseptic meatal } \\
\text { cleaning Urinary } \\
\text { catheter Urinary } \\
\text { tract infection } \\
\text { Systematic review } \\
\text { Meta-analysis }\end{array}$ & None Stated & & $\begin{array}{l}\text { There were no } \\
\text { differences in } \\
\text { CAUTI rates. }\end{array}$ & $\begin{array}{l}\text { This review is } \\
\text { strengthened by } \\
\text { the development } \\
\text { of a protocol that } \\
\text { aided the design } \\
\text { and conduct of the } \\
\text { systematic review } \\
\text { and meta-analysis. } \\
\text { The studies were } \\
\text { clinically } \\
\text { heterogeneous } \\
\text { with regards to } \\
\text { diversity }\end{array}$ & $\mid$ \\
\hline $\begin{array}{l}\text { Hollenbeck, C. S., } \\
\text { \& Schilling, A. L. } \\
\text { (2018). The } \\
\text { attributable cost of } \\
\text { catheter- } \\
\text { associated urinary }\end{array}$ & $\begin{array}{l}\text { The purpose of } \\
\text { this study was to } \\
\text { perform a } \\
\text { systematic review } \\
\text { of the literature } \\
\text { that estimates the }\end{array}$ & $\begin{array}{l}\text { CAUTI, Healthcare } \\
\text { acquired condition }\end{array}$ & $\begin{array}{l}\text { Duplicates, not a } \\
\text { cost evaluation, } \\
\text { other }\end{array}$ & & $\begin{array}{l}\text { The cost of a } \\
\text { CAUTI ranges } \\
\text { widely depending } \\
\text { on population, } \\
\text { patient acuity, and } \\
\text { cost perspective. }\end{array}$ & $\begin{array}{l}\text { A major limitation } \\
\text { of our systematic } \\
\text { review is that we } \\
\text { could not perform } \\
\text { a meta-analysis on } \\
\text { the available cost }\end{array}$ & II/A \\
\hline
\end{tabular}




\begin{tabular}{|c|c|c|c|c|c|c|c|}
\hline Citation & Question & Search Strategy & $\begin{array}{l}\text { Inclusion/ } \\
\text { Exclusion Criteria }\end{array}$ & $\begin{array}{l}\text { Data Extraction and } \\
\text { Analysis }\end{array}$ & Key Findings & $\begin{array}{l}\text { Recommendation/ } \\
\text { Implications }\end{array}$ & $\begin{array}{l}\text { Level of } \\
\text { Evidence }\end{array}$ \\
\hline $\begin{array}{l}\text { tract infections in } \\
\text { the United States: } \\
\text { A systematic } \\
\text { review. American } \\
\text { Journal of } \\
\text { Infection Control, } \\
46(7), 751-757 .\end{array}$ & $\begin{array}{l}\text { attributable cost of } \\
\text { CAUTIs in the } \\
\text { United States. }\end{array}$ & & & & & $\begin{array}{l}\text { estimates found in } \\
\text { the literature }\end{array}$ & \\
\hline $\begin{array}{l}\text { Gould, D., Gaze, S., } \\
\text { Drey, N., \& } \\
\text { Cooper, T. (2017). } \\
\text { Implementing } \\
\text { clinical guidelines } \\
\text { to prevent } \\
\text { catheter- } \\
\text { associated urinary } \\
\text { tract infections } \\
\text { and improve } \\
\text { catheter care in } \\
\text { nursing homes: } \\
\text { Systematic review. } \\
\text { American Journal } \\
\text { of Infection } \\
\text { Control, 45(5), } \\
471-476 .\end{array}$ & $\begin{array}{l}\text { To help develop an } \\
\text { intervention to } \\
\text { improve catheter } \\
\text { management and } \\
\text { reduce CAUTI } \\
\text { specifically in the } \\
\text { nursing home } \\
\text { environment } \\
\text { where } \\
\text { implementation } \\
\text { of infection } \\
\text { prevention guideli } \\
\text { nes is reported to } \\
\text { be more } \\
\text { challenging than in } \\
\text { hospitals. }\end{array}$ & \begin{tabular}{|l} 
Catheter-associated \\
urinary tract infection, \\
Clinical , \\
Infection prevention, \\
and control \\
Nursing homes, \\
Long-term care, \\
Systematic review
\end{tabular} & $\begin{array}{l}\text { Duplicates } \\
\text { removed, full text, } \\
\text { nursing home }\end{array}$ & & $\begin{array}{l}\text { Prevention of } \\
\text { catheter- } \\
\text { associated urinary } \\
\text { tract infection in } \\
\text { nursing homes has } \\
\text { received little } \\
\text { clinical or research } \\
\text { attention. Studies } \\
\text { concerned with } \\
\text { whole guideline } \\
\text { implementation } \\
\text { emerged as } \\
\text { methodologically } \\
\text { poor using } \\
\text { recognized criteria } \\
\text { for critically } \\
\text { appraising } \\
\text { epidemiologic } \\
\text { studies concerned } \\
\text { with infection } \\
\text { prevention. }\end{array}$ & $\begin{array}{l}\text { Although extensive } \\
\text { and thorough } \\
\text { electronic searches } \\
\text { were undertaken, } \\
1 \text { of the } 12 \text { studies } \\
\text { identified for } \\
\text { detailed review } \\
\text { was obtained by } \\
\text { hand-searching. It } \\
\text { is possible that } \\
\text { other relevant } \\
\text { studies were not } \\
\text { identified. } \\
\text { Recently } \\
\text { conducted studies } \\
\text { were reported too } \\
\text { briefly for } \\
\text { adequate critique. } \\
\end{array}$ & \begin{tabular}{|c}
$1 / A$ \\
\\
\\
\\
\end{tabular} \\
\hline
\end{tabular}


Appendix C

Gap Analysis Test Questions

(Dumont \& Wakeman, 2010; Ferguson, 2018)

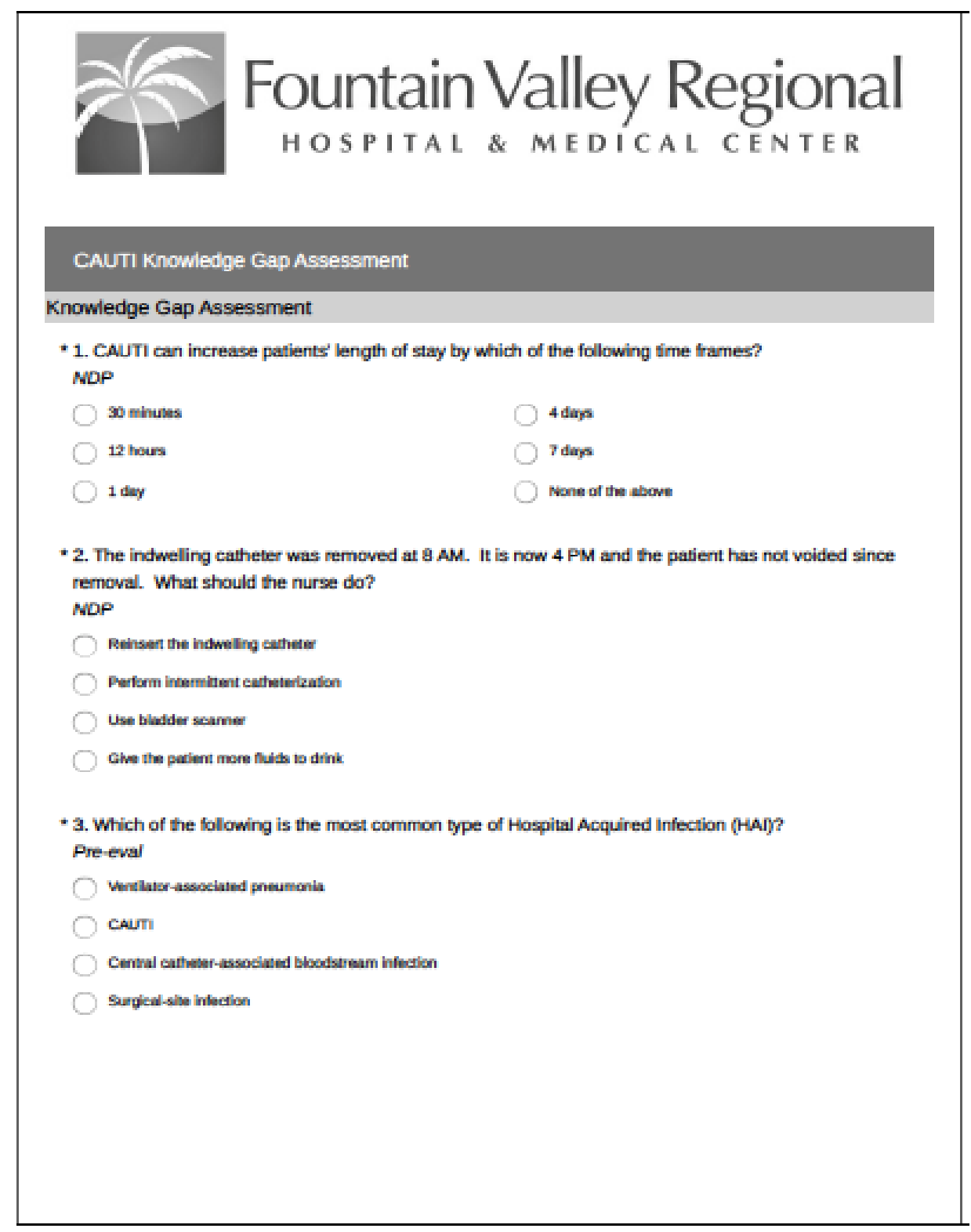




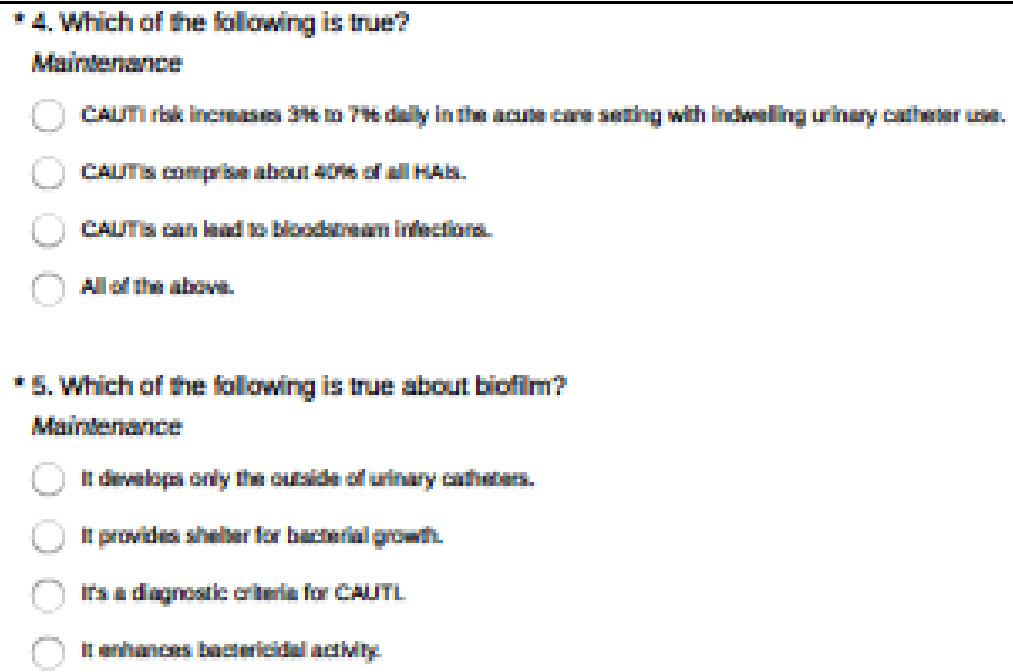

*6. All of the folowing are indicators of an indwelling urinary catheter on a medical/surgical unit except? Pre-eval

(1) Ade urinary retention

Wound heding promotion in patlents with of perinated wound

Sriet intake and Ouput (ISC) montoring

End of life coenfort case

*7. Which of the folowing provides the safest ouscome for a patent with urinary resention? Pre-eval

inserminent stulght cathmerization

indwelling urinary cattmat

* 8. Is a Foley catheter indicated for urinary incontinence (in a patient without a skin breakdown)? Pre-eval
(1) Yes
No

*9. Is a Foley catheter indicated in a patient who is unable to stand to void? Pre-eval

(1) res

No 
* 10. If a patient has been newly prescribe laskx, or has been prescribed an increased dose of this or another diuretic, is it reasonable to place a Foley catheter?

Pre-eval

Thes

No

*11. A bladder scanner shows over $400 \mathrm{CC}$ of urine present. Which of the following would be the appropriase next step?

Pre-eval

Wilt another six hours and sean the bladder again.

( Itroet a Foley catheser

(1) Perform an intemintent seraighe cathener

(1) Assess petient pein and coeffort 